\title{
36. CRETACEOUS CALCISPHERULIDS OF THE FALKLAND PLATEAU, LEG 71, DEEP SEA DRILLING PROJECT ${ }^{1}$
}

\author{
V. A. Krasheninnikov, Geological Institute of the U.S.S.R. Academy of Sciences, Moscow, U.S.S.R. \\ and \\ I. A. Basov, Institute of the Lithosphere of the U.S.S.R. Academy of Sciences, Moscow, U.S.S.R.
}

\begin{abstract}
Thirteen species of calcispherulids are described from the 361-meter thick Cretaceous sequence of Hole 511. New taxa include seven new species and one new genus: Pithonella loricata, $P$. squalida, $P$. miniaperta, $P$. squamosa, $P$. transitoria, $P$. usheri, the new genus Sliteria and its type species $S$. pentagonalis. Calcispherulids first occur in the mid-Albian and are found throughout the Cretaceous, except in the Coniacian-Santonian, where they are almost entirely absent except for mass concentrations of the new genus Sliteria. Five distinct assemblages are recognized in the (1) Albian and lower upper Cenomanian (6 species), (2) uppermost Cenomanian, Turonian, and perhaps Coniacian (3 species), (3) Santonian (1 species), (4) Campanian (5 species), and (5) uppermost Campanian-lower Maestrichtian (5 species). Discussed also is the evolutionary development of wall types and the global biogeography of the calcispherulid assemblage.
\end{abstract}

\section{INTRODUCTION}

Microfossils referred to the family Calcisphaerulidae are well known from the Upper Jurassic to lower Paleocene (Danian stage) deposits on land and in the oceans. Many authors have noted the uncertain systematic position of this group of fossils, which have usually been considered as algae, either freely drifting (Banner, 1972) or benthic (Bein and Reiss, 1976). Recent investigations of their inner structure (Keupp, 1979) make it possible to regard these microfossils as calcareous cysts of dinoflagellates (Calciodinelloidea).

Though calcispherulids have been known to paleontologists for over a hundred years, their stratigraphic distribution and systematics have not yet been thoroughly studied, both because of the difficulties associated with investigating them by the light microscope and in thin section, and because they are rarely encountered in large quantities in marine deposits on the continents.

The situation changed sharply when numerous calcispherulids began to be derived from weakly consolidated oceanic sediments, and then investigated in the scanning electron microscope. It became possible to study both their outer and inner structure, and systematic description and studies of stratigraphic distribution appeared.

Bolli (1974) described 23 new species of calcispherulids belonging to the genus Pithonella (four of them under open nomenclature) and the new genus Andriella from Upper Jurassic and Cretaceous sediments of the southeastern Indian Ocean (Leg 27). Bolli considered the form of shell and aperture and the structure of the wall (its lamination pattern, size, shape, and the disposition of crystals forming its layers) as main species features. He also showed change in calcispherulid associations in Upper Jurassic and in Lower and Upper Creta-

\footnotetext{
${ }^{1}$ Ludwig, w. J., Krasheninnikov, V. A., et al., Init. Repts. DSDP, 71: Washington (U.S. Govt. Printing Office).
}

ceous sediments. Bolli's investigation drew the attention of micropaleontologists to calcispherulids and stimulated further studies of these fossils.

Rögl (1976) described four new species of calcispherulids from Danian deposits at Site 323 in the southeastern Pacific (Leg 35). This study, interesting from both stratigraphic and paleoclimatic points of view, showed that calcispherulids did not disappear at the top of the Maestrichtian but continued to exist in the high paleolatitudinal belt during early Paleocene (Danian) time.

Bolli (1978) described and illustrated seven calcispherulid species belonging to the genera Pithonella and $\mathrm{Bo}$ netocardiella from Cretaceous and lower Paleocene (Danian) sediments of the Angola and Cape basins (Sites 361,363 , and 364, Leg 40). This author outlined three stratigraphic species assemblages, succeeding one another up the section. The first group consists of Pithonella cf. $P$. sphaerica, $P$. cf. $P$. ovalis, and Bonetocardiella cf. $B$. conoidea, and is encountered in the uppermost Aptian and the entire Albian section. The second group is represented by two genetically related species-oval $P$. cooki and more elongated $P$. krasheninnikovi-and is found in the Campanian-Maestrichtian. The third group includes spherical Pithonella cf. $P$. bollii and $P$. titanoplax and is encountered in lower Paleocene sediments. P. titanoplax, according to Bolli (1978), is a descendent of $P$. krasheninnikovi, to which it is connected by the form of $P$. cooki that is characterized by an oval shell.

Abundant calcispherulids were identified by Pflaumann and Krasheninnikov (1978) from Cretaceous deposits in the Morocco Basin (Site 370) and within the continental slope off Spanish Sahara (Site 369, Leg 41), eastern North Atlantic. Their assemblage includes nine new Pithonella species, two previously described, and two species of the same genus under open nomenclature. Analyzing all calcispherulid findings from the Mesozoic and Danian deposits of the Indian, Pacific, and Atlantic oceans, Pflaumann and Krasheninnikov (1978) outlined five morphologic groups, differing in the form 
of their shells, wall structure, and the presence or absence of pores: (1) spherical shell with single-layered wall, pores absent; (2) spherical shell with single-layered porous wall; (3) oval shell with single-layered wall, pores absent; (4) spherical shell with multilayered wall; (5) oval shell with multilayered wall. The calcispherulids quite definitely show the following stratigraphic assemblages: Upper Jurassic, Neocomian, Aptian-Albian, Coniacian-Santonian, and Campanian-Maestrichtian. Now a Danian assemblage can also be added.

There are obvious difficulties in studying calcispherulids. Precise identification of the majority of recently described species is possible only by the scanning electron microscrope. The taxonomic features (specific and generic) of calcispherulids are not distinct. Comparison of identifications made by different techniques (light or scanning electron microscope) is unreliable (Bolli, 1974). The absence of distinct criteria for the identification of calcispherulid species does not permit us to determine unequivocally their stratigraphic distribution. Nevertheless, it is already clear that this group of microfossils is widely distributed both geographically and stratigraphically and may well serve as an important subsidiary tool in the stratification of Jurassic, Cretaceous, and lower Paleocene (Danian) deposits.

This article presents the results of a preliminary study of calcispherulids encountered in the Cretaceous sediments of the Falkland Plateau (Site 511, Leg 71). The significance of this material resides also in the fact that these calcispherulids appear in Cretaceous deposits from the moderate climatic belt, as is true for planktonic foraminifers.

\section{CALCISPHERULID DISTRIBUTION IN SITE 511 CRETACEOUS SEDIMENTS}

Site $511\left(51^{\circ} 00.28^{\prime} \mathrm{S}, 46^{\circ} 58.30^{\prime} \mathrm{W}\right.$; water depth 2589 m) (Fig. 1) was drilled at the western extremity of the Maurice Ewing Bank (the Falkland Plateau). The stratigraphic subdivisions determined within the Cretaceous sequence by planktonic foraminifers are BarremianAptian (Samples 511-57,CC to 511-62,CC), Albian (Samples $511-49-5,120-122 \mathrm{~cm}$ to $511-57-6,11-13 \mathrm{~cm}$ ), upper Cenomanian (Samples 511-48-1, 70-72 cm to 51149-5, 102-104 cm), Turonian (Samples 511-47-3, 44-46 $\mathrm{cm}$ to $511-48-1,35-37 \mathrm{~cm}$ ), undifferentiated ConiacianSantonian (Samples 511-44-1, 44-46 cm to 511-46,CC), Santonian (Samples 511-41, CC to 511-43,CC), Campanian (Samples 511-27-1, 32-34 cm to 511-41-3, 55-57 $\mathrm{cm}$ ), uppermost Campanian-lower Maestrichtian (Samples 511-23-1, 27-29 cm to 511-26,CC) (Krasheninnikov and Basov, this volume).

Barremian-lowermost Albian sediments are represented by black shales with extremely low fossil remains. The Albian is characterized by calcareous nannofossilrich clays and silts. All these sediments were deposited in shallow water (depths $100-400 \mathrm{~m}$ ). The black shales formed in a sea basin with restricted water circulation and anoxic bottom waters; the Albian sediments with rich planktonic microorganisms formed in a shallow-water, open oceanic basin. Upper Cretaceous sediments are composed of nannoplanktonic and foraminiferal chalk and oozes with intercalations of slightly calcareous and noncalcareous clays (dissolution facies) accumulated in an open oceanic basin at depths of 1500-2000 meters (Basov and Krasheninnikov, this volume). Cretaceous deposits are up to 361 meters thick. They overlie, without visible disconformity, black shales of the Upper Jurassic and in turn are unconformably overlain by Paleogene sediments.

Calcispherulids appear in the section beginning from the middle part of the Albian and are found throughout the Upper Cretaceous sediments except in the Coniacian-Santonian interval, where they are almost entirely absent. They are irregularly distributed and as usual are present in small amounts. High concentrations of calcispherulids are found in some Albian layers, as well as in the lower part of the upper Cenomanian and Turonian, and are typical of nanno-foraminiferal oozes of the upper Campanian-lower Maestrichtian.

The Coniacian-Santonian interval, characterized by distinctive, multiedged microfossils of uncertain systematic attribution, present in great amounts, is quite enigmatic. Sometimes these fossils are also found in Turonian deposits and in the middle Campanian. Sliter, who first (1977) described these microfossils as "incertae sedis" from the Hole 327A Santonian sediments (Leg 36, the Falkland Plateau) and published excellent illustrations, considered them similar to marine algae. Thus, if our suggestion that these microfossils described as "incertae sedis" are calcispherulids is correct, calcispherulids characterize all the Upper Cretaceous subdivisions.

The Cretaceous sediments of Site 511 contain 13 species of calcispherulids, seven of them are new. Their distribution and relative abundance are shown in Figure 2.

\section{Albian}

The clayey limestones and nannoforaminiferal chalk of the Albian are characterized by relatively diverse calcispherulids. In the lower part of the Albian, just above layers with the planktonic foraminifer Ticinella roberti, Pithonella loricata n.sp. is present. In some samples (511-50,CC and 511-51-1, 60-62 cm), this species forms mass accumulations; in the others it is quite rare. Middle Albian sediments (Cores 511-51 and 511-52) lack calcispherulids. They are most abundant and diverse in upper Albian sediments, where $P$. thayeri, $P$. miniaperta n.sp., $P$. sheilasantawae, and $P$. squamosa n.sp. were found.

\section{Upper Cenomanian}

Pithonella thayeri, $P$. sheilasantawae, $P$. miniaperta n.sp., and $P$. squamosa n.sp. pass from the Albian into the lower part of the upper Cenomanian. In contrast to underlying sediments, they are present here only in small amounts and are often very rare. These species are accompanied by $P$. squalida. The latter is stratigraphically restricted and is represented by numerous specimens. The uppermost Cenomanian is characterized by dissolution facies; the only species that appears is $P$. squamosa, which is very rare.

\section{Turonian}

Dissolution facies also prevail in the Turonian interval, where three species of calcispherulids were identified. Pithonella miniaperta continues here from the up- 


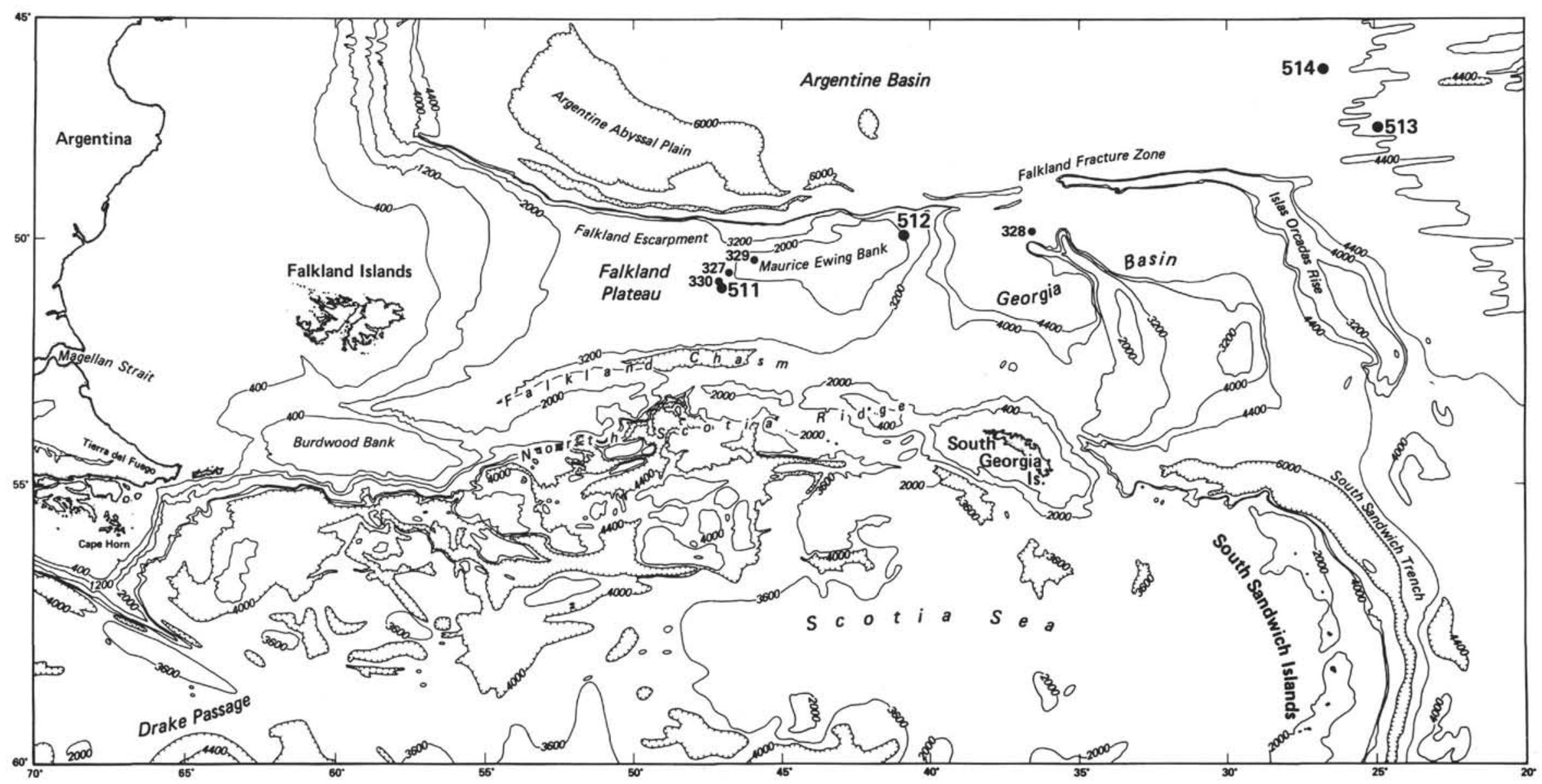

Figure 1. Location of Leg 71 sites. 


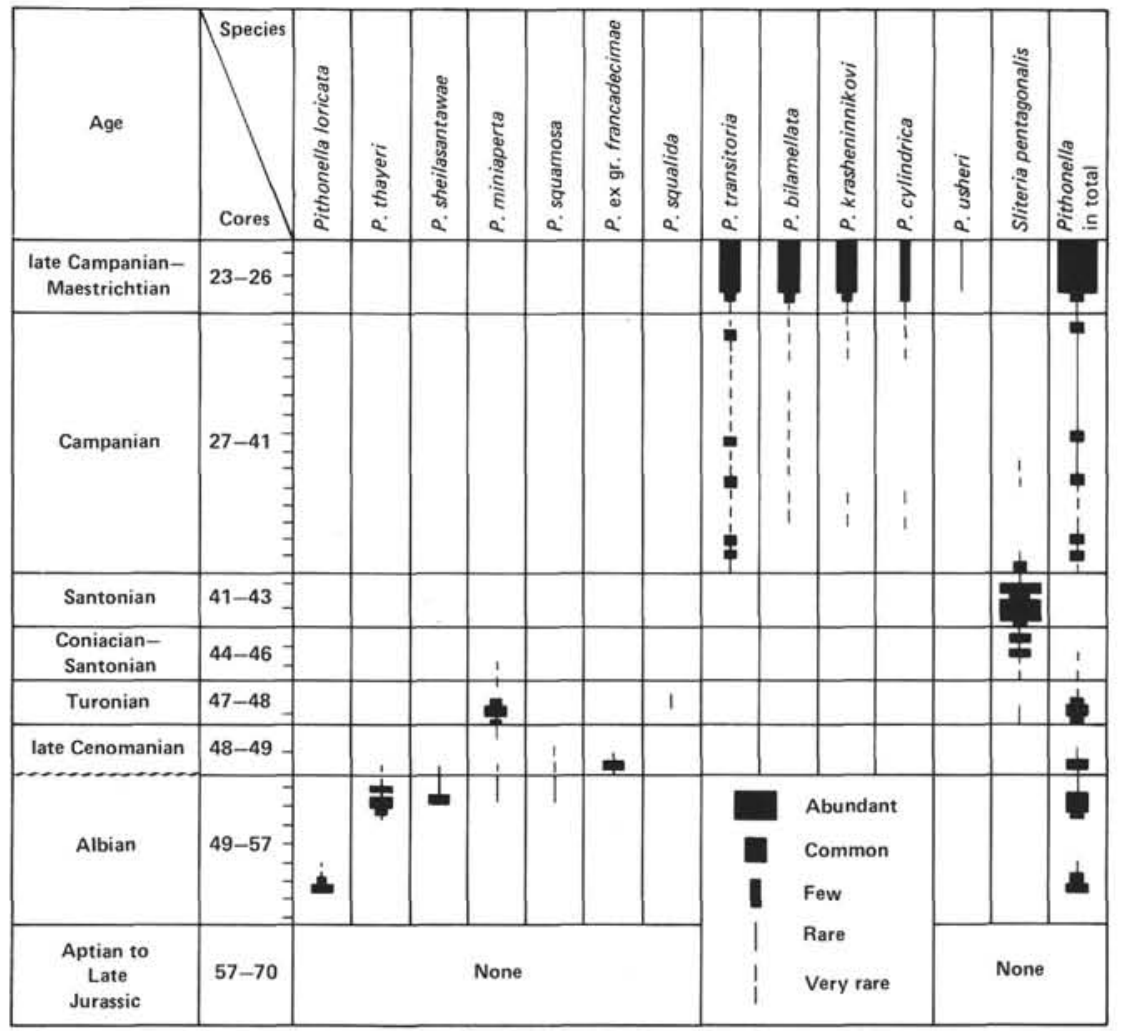

Figure 2. Distribution and abundance of calcispherulids in Cretaceous sediments of Site 511.

per Cenomanian and is present in great amounts in the middle Turonian. The species $P$. ex gr. francadecimae is represented by very rare specimens. Extremely peculiar Sliteria pentagonalis $\mathrm{n} . \mathrm{sp}$, widely distributed in younger sediments, appears at the base of the Turonian; in the Turonian itself it is very rare.

\section{Coniacian-Santonian}

The species composition of calcispherulids is very poor in the undifferentiated Coniacian-Santonian sediments and resembles that of the Turonian. In the lower part of the section, very rare Sliteria pentagonalis is present, together with Pithonella miniaperta $\mathrm{n} . \mathrm{sp}$. In the upper half, $P$. miniaperta disappears completely, whereas $S$. pentagonalis is constantly present, forming mass concentrations in the interval 511-45-2, 48-100 cm and in Sample 511-44-3, 44-46 cm. In the last sample pyrite is abundant.

\section{Santonian}

"True" calcispherulids are absent in the Santonian sediments. Sliteria pentagonalis, only conventionally referred to this group of microfossils, becomes widely distributed. This species is encountered throughout the whole section, as a rule in large amounts. In samples where it is abundant enough, one can find all the morphological varieties (Plates 11 and 12), from sharp-edged (juvenile?) forms with many apertures to subspherical (adult?) specimens with one main aperture and several subsidiary ones closed to different degrees. In some un- derlying sediments pyrite is commonly associated with abundant $S$. pentagonalis.

\section{Campanian}

The thick pile of Campanian sediments $(137.5 \mathrm{~m})$ represented by the alternation of calcareous nannofossil and foraminiferal clays and claystones with slightly calcareous or noncalcareous clay (dissolution facies) is characterized by four species of calcispherulids. As a rule they are very irregularly present and only rarely form somewhat noticeable concentrations. Pithonella transitoria n.sp., appearing at the base of the Campanian, is most common and is almost constantly present. In the lower half of the Campanian separate samples contain Sliteria pentagonalis, usually found as very rare specimens of subspherical shape with half-closed subsidiary apertures. In the Campanian deposits from 511-38-5, 48$50 \mathrm{~cm}$ upward in the section, oval $P$. bilamellata and spindle-shaped $P$. krasheninnikovi are developed; they are sporadic and rare.

On the whole, $P$. transitoria n.sp. is most common among Campanian calcispherulids but only occasionally does it form noticeable concentrations.

\section{Uppermost Campanian-Lower Maestrichtian}

White and pale gray foraminiferal and nannoforaminiferal oozes and calcareous clays ( $14 \mathrm{~m}$ thick) of this age (most likely they are lower Maestrichtian) contain high though not very diverse concentrations of calcipherulids (five species only). Pithonella transitoria and 
P. krasheninnikovi are the most common; $P$. bilamellata and $P$. cylindrica are almost equally present. All of these appeared in the Campanian; they are very abundant in Maestrichtian sediments.

$P$. usheri n.sp. is a peculiar representative of calcispherulids in the stratigraphic interval under consideration. This species does not form any noticeable concentrations, but it is constantly present in all samples, being distinguished by its pearlike (or droplike) shape and relatively large size, all of which allow us to identify it under the light microscope.

\section{DISCUSSION}

From samples from a single site only, it is difficult to draw convincing conclusions, and ours are quite preliminary here. Some peculiarities of the systematic composition of calcispherulids and their stratigraphic distribution in the Cretaceous deposits of Site 511 are difficult to explain.

The systematic composition of calcispherulids from the Cretaceous sediments of the Falkland Plateau is relatively poor (13 species), though our investigations cannot be considered exhaustive. Perhaps the impoverishment of calcispherulids reflects the existence of temperate/subtropical climatic conditions in the high latitudes of the South Atlantic during the Cretaceous. Calcispherulids are in this respect similar to other groups of calcareous plankton (foraminifers and nannoplankton) from the Cretaceous deposits of the Falkland Plateau. In the Albian sediments of Site 511, many calcispherulid species described by Bolli (1974) from synchronous deposits of the southeastern Indian Ocean are absent. This seems quite strange, since according to paleogeographical reconstructions (Sliter, 1977) the region of the Indian Ocean under study and the Falkland Plateau were in similar paleolatitudes. Some species of calcispherulids (Pithonella porosa, P. longiporosa and P. amplicrystallina), first described by Pflaumann and Krasheninnikov (1978) from Albian sediments of the Morocco Basin (Site 370) and from Campanian-Maestrichtian deposits of the Spanish Sahara continental slope (Site 369), are also absent.

Meanwhile, there are some calcispherulid species common to the Cretaceous sediments of all three areas. $P$. thayeri and P. krasheninnikovi are encountered in the southeastern Indian Ocean, off the western coast of Africa, and on the Falkland Plateau. P. sheilasantawae is found in the Albian of the southeastern Indian Ocean and on the Falkland Plateau; P. cylindrica and $P$. bilamellata are common to the Campanian and Maestrichtian of the Spanish Sahara slope and the Falkland Plateau.

The peculiar feature of Falkland Plateau calcispherulids is the presence of $P$. loricata, $P$. miniaperta, $P$. squamosa, $P$. transitoria, $P$. squalida, and $P$. usheri, as well as the abundance of Sliteria pentagonalis. It is not clear whether this peculiarity arises from biogeographic causes and endemic species development, the location of the area under study in the high latitudes of the South Atlantic, or merely insufficient knowledge of this group.
There are distinct changes in calcispherulid assemblages throughout the section that allow us to outline five stratigraphic units in the Cretaceous sediments of Site 511.

1) The oldest subdivision corresponds to the Albian and the lower part of the upper Cenomanian. Six calcispherulid species ( $P$. loricata, $P$. thayeri, $P$. sheilasantawae, $P$. miniaperta, $P$. squamosa, and $P$. squalida) are encountered here. As a rule, only a small number of specimens is present, occasionally forming mass concentrations. Changes within this interval are insignificant. $P$. loricata is found in the Albian only, and P. squalida appears in the Cenomanian.

2) This includes the uppermost Cenomanian, Turonian, and perhaps the Coniacian. It is characterized by a calcispherulid assemblage extremely poor in its species composition and abundance. Only two species of Pithonella ( $P$. miniaperta and $P$. ex gr. francadecimae) are identified, along with extremely rare $S$. pentagonalis. The sediments of this interval are represented mainly by dissolution facies.

3) This subdivision corresponds clearly to the Santonian. Representatives of Pithonella are completely absent, and $S$. pentagonalis, conventionally referred to calcispherulids, is the only developed species. Specimens of S. pentagonalis are abundant. Sliter (1977) also notes mass shell concentrations of this species (incertae sedis after Sliter) in Santonian clays of Site 327 at the Falkland Plateau.

It is mysterious that this species is present here in mass amounts, whereas other species of calcispherulids are completely absent. As mentioned earlier, some samples with high concentrations of $S$. pentagonalis contain abundant pyrite. Perhaps this phenomenon testifies to extreme life and burial conditions which unfavorably affected the activity of other species or the preservation of their shells in sediments.

4) This subdivision embraces the Campanian and is characterized by a quite different assemblage of calcispherulids: $P$. transitoria, $P$. bilamellata, $P$. krasheninnikovi, and $P$. cylindrica. They are not present in quantity. $P$. transitoria is present constantly and most frequently, sometimes forming noticeable concentrations. In the lower part of the Campanian, $S$. pentagonalis is found, though in separate samples and as very rare specimens only.

5) The last subdivision corresponds to the uppermost Campanian-lower Maestrichtian (most probably lower Maestrichtian) and contains abundant calcispherulids. The assemblage includes $P$. transitoria, $P$. krasheninnikovi, P. bilamellata, and P. cylindrica; $P$. usheri appears for the first time. It is interesting to note that planktonic foraminifers completely disappear in the slightly calcareous Maestrichtian clay at the top of the Cretaceous section, although calcispherulids remain quite numerous. They were obviously more tolerant of the environment (or more resistant to dissolution) than foraminifers.

Changes in calcispherulid assemblages in the Cretaceous sediments of Site 511 are caused by their evolutionary development or the influence of bionomic and bury- 
ing conditions-it is difficult to distinguish the precise effect of each of these factors. Evolutionary development ought to be visible in consequent changes in distinct morphological groups of calcispherulids.

In Albian, Cenomanian, Turonian, and probably Coniacian sediments three groups of calcispherulids may be traced: (1) calcispherulids with a single-layered wall formed by large and small crystals of irregular shape $(P$. thayeri); (2) calcispherulids with a double-layered wall composed of cobblestone-shaped crystals ( $P$. sheilasantawae, P. squalida); (3) calcispherulids with a double or three-layered wall, the outer layer of which is composed of flat platelike crystals arranged like tiles $(P$. loricata, $P$. miniaperta, and $P$. squamosa). This group is not yet known from other oceanic regions.

In Santonian sediments $S$. pentagonalis is extremely widely distributed, but Pithonella species are completely absent.

In the Campanian and Maestrichtian, highly organized calcispherulids with a double-layered wall and smooth surface are abundant. The outer layer of these forms is composed of small elongated crystals, the long axis of which is parallel to the surface, whereas the inner layer consists of large, massive crystals.

All these data suggest that calcispherulids of the Cretaceous deserve further detailed investigation.

\section{SYSTEMATIC DESCRIPTION}

\section{Family CALCISPHAERULIDAE Bonet, 1956 Genus PITHONELLA Lorenz, 1901}

Pithonella thayeri Bolli

(Plate 1, Figs. 1-9)

Pithonella thayeri Bolli, 1974, p. 853, pl. 1, figs. 9-12; pl. 3, figs. 912; pl. 9, figs. 1-12; pl. 21, fig. 3 .

Description. Test small, spherical, subspherical or slightly ovoidal with a single-layered wall, up to $10-12 \mu \mathrm{m}$ thick. Calcite crystals composing the wall are usually large (8-12 $\mu \mathrm{m})$, with a subordinate quantity of smaller crystals $(3-5 \mu \mathrm{m})$. They are of irregular shape and size, often shapeless. The crystals are tightly arranged with small pores rarely and randomly dispersed on the surface. The outer surface is rough; separate crystals protrude above it. Inner surface is generally smooth with some large crystals (perhaps of secondary origin) protruding into the inner space. The aperture is a small round opening (diameter about $15 \mu \mathrm{m}$ ) situated symmetrically at the end of a test and surrounded by crystals similar to those composing the whole wall. Sometimes the aperture is closed.

Dimensions. Diameter up to $75 \mu \mathrm{m}$.

Occurrence. Interval from Sample $511-49-4,44-46 \mathrm{~cm}$ to Sample $511-51, \mathrm{CC}$

Age. Albian (most probably the late part)-late Cenomanian.

Remarks. $P$. thayeri was originally described by Bolli (1974) from the Upper Jurassic of the Argo Abyssal Plain, Indian Ocean. Later this species was discovered by Pflaumann and Krasheninnikov (1978) in the Valanginian to Barremian sediments of the Morococo Basin, Atlantic Ocean. The morphological features of $P$. thayeri from these localities and from the Albian-Cenomanian of the Falkland Plateau are similar, but the stratigraphic range of the species becomes very wide. Evidently $P$. thayeri with morphologically simple test requires careful investigation.

\section{Pithonella sheilasantawae Bolli}

(Plate 2, Figs. 1-8)

Pithonella sheilasantawae Bolli, 1974, p. 854, pl. 4, figs. 1-4; pl. 13, figs. $3-7$; pl. 22, fig. 4.

Description. Test small, spherical or subspherical, with a doublelayered wall. Calcite crystals forming the wall are of medium size (av. diameter 3-4 $\mu \mathrm{m}$ ) and irregular, rounded form, closely arranged, which gives the test surface the appearance of a cobblestone pavement. The wall is up to $10 \mu \mathrm{m}$ thick. The outer layer and thinner inner layer make contact with a loose arrangement of calcite crystals. The aperture is a very large round opening, almost equal in diameter to the largest one, which gives an applelike shape to the outline.

Dimensions. Diameter up to $70 \mu \mathrm{m}$.

Occurrence. Rare and very rare specimens in the interval from Sample 511-49-4, 44-46 cm to Sample 511-50-3, 44-46 cm except Samples $511-50-2,44-46 \mathrm{~cm}$ and $511-50-3,44-46 \mathrm{~cm}$, where they are common.

Age. latest Albian to earliest late Cenomanian.

Remarks. $P$. sheilasantawae resembles some other species of Pithonella which have a spherical test with large aperture. It differs from $P$. rockeri by the double-layered wall and the absence of separate large crystals on the surface and from $P$. francadecimae by its cobblestonelike surface. A remote similarity with Bonetocardiella conoidea (Bonet) is apparent, but the genus Bonetocardiella is characterized by a heart-shaped test and a medium-sized aperture that is situated in a depression.

\section{Pithonella loricata n.sp.}

(Plate 3, Figs. 1-7)

Derivatio nominis. loricata (Latin), "dressed in a coat of mail."

Type locality. South Atlantic, Falkland Plateau, Site 511.

Type level. Albian.

Description. Test small, spherical, with a double-layered wall. The outer and inner layers are equal in thickness (about $6 \mu \mathrm{m}$ ) and composed of irregularly shaped and sized platelike calcite crystals, tightly arranged and forming a relatively even outer surface with randomly dispersed fine pseudopores. The wall is $12 \mu \mathrm{m}$ thick. The surface between the outer and inner layers is distinct because of the loose arrangement of crystals near it. The aperture is not visible in almost all the specimens. One specimen (Plate 3, Fig. 7) has a large opening (diameter $45 \mu \mathrm{m}$ ) which perhaps represents the aperture.

Dimensions. Diameter up to $90 \mu \mathrm{m}$.

Occurrence. Interval from Sample 511-54-3, 34-36 cm to Sample $511-55-3,34-36 \mathrm{~cm}$.

Age. Albian.

Remarks. The species under consideration is similar to $P$. robinsoni Bolli, but the latter has a small aperture and its outer layer consists of a combination of large platelike crystals and small angular ones.

\section{Pithonella squalida n.sp.}

(Plate 4, Figs. 1-8)

Derivatio nominis. squalida (Latin), "uneven, rough," refers to the character of the test surface.

Type locality. South Atlantic, Falkland Plateau, Site 511.

Type level. upper Cenomanian.

Description. Test is very small, compressed, ovoidal, sometimes eggshaped, with a double-layered wall. Calcite crystals composing the outer layer, 5-6 $\mu \mathrm{m}$ thick, are massive and tightly packed; the diameter of the largest crystals is about $3-5 \mu \mathrm{m}$, and they have rounded or semi-rounded contours, giving the test surface an uneven character like a cobblestone pavement. Rare, minute pores (pseudopores?) are seen on the whole surface. The inner layer (about $2-4 \mu \mathrm{m}$ thick) consists of smaller calcite crystals. The inner surface is also uneven, like a cobblestone pavement; large crystals protrude into the inner space but they are possibly of secondary genesis. The aperture is elongated and slitlike, surrounded by crystals larger than those on the rest of the surface.

Dimensions. The long axis of the test is up to $60 \mu \mathrm{m}$, large diameter up to $50 \mu \mathrm{m}$, small diameter $45 \mu \mathrm{m}$; the length of the aperture is $25-30$ $\mu \mathrm{m}$, the width $10-12 \mu \mathrm{m}$.

Occurrence. Interval from Sample 511-49-4, 44-46 cm to Sample $511-49-5,102-104 \mathrm{~cm}$.

Age. earliest late Cenomanian.

Remarks. On account of the cobblestone appearance of the test surface the species resembles 3 other species: $P$. rocker $i$ Bolli, of which the wall contains large platelike crystals on a background of small cobblestonelike ones; P. gustafsoni Bolli, which is one-layered with a spehrical test and small circular aperture; and P. johnstonei Bolli, which is also characterized by a one-layered wall and spherical test. 
Pithonella miniaperta n. sp.

(Plate 5, Figs. 1-8)

Derivatio nominis. miniaperta (Latin), "with a small aperture." Type locality. South Atlantic, Falkland Plateau, Site 511. Type level. Albian.

Description. Test is small and spherical with a three-layered wall. The outer layer consists of relatively large platelike calcite crystals (3-4 $\mu \mathrm{m}$ in diameter), with irregular outlines, arranged like tiles, closely packed, often protruding above the surface, to which they give an uneven character. The second layer (interlayer) is composed of smaller, loosely arranged crystals with a lot of interspace between them. The third (inner) layer consists of large, flat crystals, 5-6 $\mu \mathrm{m}$ in diameter, loosely packed and forming a very uneven surface. The aperture is a small circular opening with an uneven edge.

Dimensions. Diameter up to $90 \mu \mathrm{m}$. Thickness of the outer, intermediate, and inner layers is $4-5 \mu \mathrm{m}, 10 \mu \mathrm{m}$, and about $3 \mu \mathrm{m}$, respectively. The aperture diameter is about $25 \mu \mathrm{m}$.

Occurrence. Interval from Sample 511-45, CC to Sample 511-50-2, $44-46 \mathrm{~cm}$.

Age. Albian-Coniacian.

Remarks. Structure of the outer layer (platelike crystals arranged like tiles) is similar to that of $P$. loricata but the latter is distinguished by the double-layered wall and large aperture (usually the aperture is absent). Three-layered $P$. heirtzleri Bolli, with peel-like, very thin inner layer differs in that the outer and middle layers are of a different crystal type. $P$. miniaperta resembles $P$. guttula Pflaumann and Krasheninnikov but the wall of $P$. guttula is quite differently constructed (outer layer is without tile arrangement of crystals, inner layer has fine needle-shaped crystals).

\section{Pithonella squamosa n. sp.}

(Plate 6, Figs. 1-6)

Derivatio nominis. squamosa (Latin), "scaly," refers to tabular (scaly) form of crystals composing the outer wall.

Type locality. South Atlantic, Falkland Plateau, Site 511.

Type level. Albian.

Description. Test small, ovoidal, with double-layered wall. The outer layer (5-6 $\mu \mathrm{m}$ thick) is composed of calcite crystals which are columnlike in cross-section and tabular (platelike) with irregular outlines at the outer surface. Crystals are relatively tightly arranged, giving the surface a more or less smooth appearance with very fine pores (pseudopores) irregularly dispersed over the whole surface. The inner layer is thin and consists of very small crystals. The contact between these layers is loose and they are separated by some elongated cavities. The inner surface is even, with separate crystals (possibly of secondary genesis) protruding above it. The aperture is a small circular opening located symmetrically at the top of a test.

Dimensions. Long axis up to $100 \mu \mathrm{m}$ diameter, $75-80 \mu \mathrm{m}$, apertural diameter $15 \mu \mathrm{m}$.

Occurrence. Interval from Sample 511-49-6, 14-16 cm to Sample 511-51,CC

Age. Albian, possibly late Cenomanian.

Remarks. The species in question resembles $P$. loricata, taking into consideration the tabular form of the crystals on the surface and their tilelike arrangement. It differs from the latter by its ovoidal form, small aperture, and the presence of cavities between two layers. Ovoidal form, double-layered wall, and tabular outer crystals distinguish $P$. squamosa from $P$. heirtzleri.

\section{Pithonella ex gr. francadecimae Bolli}

$$
\text { (Plate 6, Figs. 7-10) }
$$

Spherical test with circular aperture and smooth surface. The outer layer is composed of tightly arranged platelike crystals with irregular outlines. The wall is pierced by distinct minute pores. The inner structure was not studied. Turonian, Sample 511-47-5, 44-46 cm.

The species under study resembles some Pithonella that have pores. Typical $P$. francadecimae Bolli differs by minute, tightly interlocked crystals visible only under high magnification $(\times 2500) ; P$. porosa Pflaumann and Krasheninnikov has a one-layered wall, with much bigger, circular or elongated pores. Evidently the form described belongs to a new species, but insufficient material prevents its proper investigation.

\section{Pithonella transitoria $\mathbf{n}$. sp.}

(Plate 7, Figs. 1-6)

Derivatio nominis. transitoria (Latin), "transitional," refers to the crystal type transitional to elongated crystals of the P. krasheninnikovi group.

Type locality. South Atlantic, Falkland Plateau, Site 511.

Type level. Campanian.

Description. Test is small, spherical, with double-layered wall. Calcite crystals forming the outer layer are of medium size, slightly elongated or irregular, with loose interspaces between them. Crystals are arranged subparallel to the test surface, resulting in a rather smooth surface. Outer layer up to $6 \mu \mathrm{m}$ thick. The inner layer, $5 \mu \mathrm{m}$ thick, consists of smaller elongated crystals, closely packed, mainly perpendicular to the smooth inner surface, with fine open interspaces. Sometimes there are large crystals protruding into the inner sphere; this is possibly due to secondary processes. Contact between these two layers is loose, with some irregular cavities. The aperture is a small circular opening surrounded by calcite crystals which protrude into the aperture, forming an uneven edge.

Dimensions. Diameter up to $70 \mu \mathrm{m}$; diameter of the aperture is about $20 \mu \mathrm{m}$.

Occurrence. Interval from Sample 511-23-1, 27-29 $\mathrm{cm}$ to Sample $511-41, \mathrm{CC}$

Age. Campanian to early Maestrichtian.

Remarks. In form this generally resembles $P$. johnstonei Bolli, which differs by its one-layered wall, the cobblestonelike pattern of the outer surface, and the very small aperture.

\section{Pithonella usheri n. sp.}

(Plate 7, Figs. 7-9; Plate 8, Figs. 1-2)

Derivatio nominis. The species is named in honor of the late John Usher, DSDP Shipboard Science Representative for Leg 71, Glomar Challenger.

Type locality. South Atlantic, Falkland Plateau, Site 511.

Type level. Maestrichtian.

Description. Test is spindle-shaped, drop-shaped, or pear-shaped with one or both ends pointed. In the cross-section perpendicular to the long axis the test is rounded; the diameter is largest in the middle part of the test. The surface is smooth with fine pseudopores (spaces between adjacent crystals). The wall consists of two layers. The outer layer is composed of small calcite crystals relatively loosely arranged; one plane of the crystals is subparallel to the test surface. In cross-section they are columnar; on the surface, crystals are elongated and form a net in which the knots are formed by clusters of three crystals arranged at a $120^{\circ}$ angle. The outer layer is up to $3 \mu \mathrm{m}$ thick. Dimensions of the crystals are length $3 \mu \mathrm{m}$, width $1.5 \mu \mathrm{m}$, thickness up to 3 $\mu \mathrm{m}$. The inner layer, $6-7 \mu \mathrm{m}$ thick, is formed by large, massive, shapeless crystals. The aperture is visible in all specimens investigated. It is usually small and rounded, $20-25 \mu \mathrm{m}$ in diameter, and often situated asymmetrically near a pointed end. The arrangement and size of crystals near the aperture do not differ from those in other parts of the test.

Dimensions. Long axis 140-150 $\mu \mathrm{m}$, diameter $90-95 \mu \mathrm{m}$.

Occurrence. Constantly present throughout the interval from Sample 511-23-1, 27-29 cm to Sample 511-26,CC. tian).

Age. latest Campanian-Maestrichtian (probably early Maestrich-

Remarks. $P$. usheri varies significantly in test shape. The most typical and abundant tests are pear-shaped (Plate 7, Fig. 8) with one end more pointed than another and a broadly rounded outline in the crosssection. Sometimes both ends of a test are equally pointed and it becomes spindle-shaped (Plate 7, Fig. 7). The aperture position varies as well. The aperture of spindle-shaped specimens occupies a more asymmetric position than that of the pear-shaped forms.

This very characteristic species belongs to the $P$. krasheninnikovi group, which is characterized by a double-layered wall of which the outer layer is composed of small, elongated crystals connected in a peculiar net and the inner layer of heavy, massive, thick crystals. The 
species is easily distinguished from other representatives of this group ( $P$. krasheninnikovi, $P$. cylindrica, and $P$. bilamellata) by its pearlike or droplike shape.

\section{Pithonella bilamellata Pflaumann and Krasheninnikov} (Plate 8, Figs. 3-8)

Pithonella bilamellata Pflaumann and Krasheninnikov, 1978, p. 822, pl. 5, figs. 5-6; pl. 6, figs. 1-2.

Description. Test is broadly ovoidal, inflated, slightly thinned at the apertural end, with two layers of calcite crystals. The outer layer is thin (about $2-3 \mu \mathrm{m}$ ) and consists of radially oriented short crystals that form a smooth outer surface where crystals are slightly elongated and are united in a net with lots of minute, angular interspaces (pseudospores). The inner layer is much thicker $(7-8 \mu \mathrm{m})$ and consists of large, massive crystals. The boundary between the two layers is very distinct. The aperture is a circular opening with an uneven border.

Dimensions. Length $80-90 \mu \mathrm{m}$, diameter $80-0 \mu \mathrm{m}$, diameter of aperture about $25 \mu \mathrm{m}$.

Occurrence. Interval from Sample 511-23, CC to Sample 511-38$5,48-50 \mathrm{~cm}$.

Age. Campanian-early Maestrichtian.

Remarks. This species was described by Pflaumann and Krasheninnikov (1978) from the Campanian-Maestrichtian sediments of the Spanish Sahara continental slope (Site 369). It differs from $P$. krasheninnikovi and $P$. cylindrica by its broadly ovoidal test, which is not spindle-shaped or cylindrical).

\section{Pithonella krasheninnikovi Bolli}

(Plate 9, Figs. 1-9; Plate 10, Figs. 1-5).

Pithonella krasheninnikovi Bolli, 1974, p. 856, pl. 7, figs. 1-5; pl. 18, figs. $10-12$; pl. 19 , figs. $1-12$; pl. 20 , figs. $1-4$; pl. 24 , figs. $1-2$.

Description. Test spindle-shaped or ovoidal, distinctly elongated, with double-layered wall. The outer layer is composed of small platelike calcite crystals arranged radially (Plate 10, Fig. 5) or obliquely to the test surface. They are columnar in the cross-section (Plate 10, Fig. 5) and clearly elongated on the test surface (Plate 10, Figs. 4-6; Plate 10 , Fig. 3), which is smooth. The outer layer is about $5 \mu \mathrm{m}$ thick; on the test surface crystal length is $2-3 \mu \mathrm{m}$, width about $1 \mu \mathrm{m}$. Crystals are arranged relatively loosely, forming a net with many angular interspaces. The inner layer is $15 \mu \mathrm{m}$ thick and consists of massive, large, densely packed crystals (Plate 10, Figs. 2, 4-5). When the outer layer is partly destroyed and removed one can see facets of these massive crystals (Plate 9, Figs. 8-9) of the inner layer. The aperture is a small, circular opening located symmetrically at the end of a test and was observed in all specimens studied.

Dimensions. Length up to $110-120 \mu \mathrm{m}$, thickness $70-80 \mu \mathrm{m}$. Diameter of the aperture varies between 15 and $25 \mu \mathrm{m}$.

Occurrence. Interval from Sample 511-23-1, 27-29 cm to Sample $511-38-5,48-50 \mathrm{~cm}$.

Age. Campanian-early Maestrichtian.

Remarks. This geographically widely distributed species was described originally from Upper Cretaceous, probably Coniacian-Santonian, sediments in the eastern Indian Ocean, Site 260 (Bolli, 1974) and then was discovered by Bolli (1978) in Campanian-Maestrichtian sediments of the South Atlantic, Walvis Ridge, Site 363, and by Pflaumann and Krasheninnikov (1978) in sediments of this age on the Spanish Sahara continental slope, Site 369.

\section{Pithonella cylindrica Pflaumann and Krasheninnikov}

(Plate 10, Figs. 6-8; Plate 11, Figs. 1-3)

Pithonella cylindrica Pflaumann and Krasheninnikov, 1978, p. 822, pl. 5, figs. 1-4.

Description. Test elongated, ovoidal, with nearly cylindrical outline (subparallel sides) and subspherical inflated poles; it consists of two layers. The smooth-surfaced outer layer is thin (up to $2 \mu \mathrm{m}$ ) and composed of columnar, tabular crystals arranged radially or obliquely to the surface, where they are elongated (up to $2 \mu \mathrm{m}$ ) and rather narrow (less $1 \mu \mathrm{m}$ ). Crystals are united in a net with many angular (quadrate or often triangular) interspaces. The inner layer is 4-5 times as thick as the outer one and is built up of large, massive crystals (Plate 11, Fig. 2). The aperture is small and rounded, with an even margin (Plate 10, Fig. 7), sometimes asymmetrically positioned at one pole of the test (Plate 11, Fig. 3).
Dimensions. Length up to $120-140 \mu \mathrm{m}$, thickness up to $80 \mu \mathrm{m}$, diameter of the aperture $10-15 \mu \mathrm{m}$.

Occurrence. Interval from Sample 511-23, CC to Sample 511-38-4, $48-50 \mathrm{~cm}$

Age. Campanian-early Maestrichtian.

Remarks. This species was found in the Campanian-Maestrichtian sediments of the Spanish Sahara continental slope, Site 369 (Pflaumann and Krasheninnikov, 1978). Our specimens of this species are identical to those. The species differs from $P$. krasheninnikovi in its subcylindrical shape with subspherical poles.

\section{Genus SLITERIA Krasheninnikov and Basov, gen. $\mathrm{n}$.} (Plate 11, Figs. 4-9; Plate 12, Figs. 1-8)

Type species. Sliteria pentagonalis gen. et sp. nov.

Derivatio nominis. This genus is named in honour of the outstanding micropaleontologist Dr. William V. Sliter, U.S. Geological Survey, Menlo Park, U.S.A.

Diagnosis. Test small, polyhedral in form, single-layered, with many apertures. Adult specimens are characterized by rounded tests with one main and numerous additional apertures. Detailed description is given in the characteristic of the type species.

Type locality. South Atlantic, Falkland Plateau, Site 511, DSDP.

Stratigraphic range. Turonian-lower Campanian.

Sliteria pentagonalis $\mathbf{n}$. $\mathbf{s p}$.

(Plate 11, Figs. 4-9; Plate 12, Figs. 1-8)

Calcareous organism incertae sedis Sliter, 1977, pp. 572-573, pl. 14, figs. 1-8.

Derivatio nominis. pentagonalis (Greek), "with five angles," refers to the five-sided symmetry of the test.

Type locality. South Atlantic, Falkland Plateau, Site 511.

Type level. Santonian.

Description. Test is a small polyhedron consisting of 12 pentagonal facets. The edges (partitions) between facets are sharp and distinct in the juvenile specimens but later become more rounded and less distinct, which results in a more rounded, almost spherical appearance. The wall is single-layered, composed of tabular (platelike) calcite crystals, often of irregular shape, arranged perpendicularly to the wall surface. Thickness of the wall varies from $10 \mu \mathrm{m}$ near the aperture to $15-18 \mu \mathrm{m}$ near thickened partitions. The outer surface is almost smooth, with rare and minute pseudopores, irregularly dispersed. The inner surface is very smooth, with dense, tiny pores.

All facets have apertures (one in each facet) which are round or oval openings situated at their centers. In juvenile specimens, all apertures are equal and about $10 \mu \mathrm{m}$ in diameter. In adult specimens, one can distinguish a main aperture, which remains wide open and supplementary apertures that are open to different extents; some are almost or completely closed.

Dimensions. Diameter 75-90 $\mu \mathrm{m}$.

Occurrence. This species is present in the interval from Sample $511-36-2,70-72 \mathrm{~cm}$ to Sample $511-48-1,18-20 \mathrm{~cm}$. It is abundant in the interval from Sample 511-41-2, 26-28 cm to Sample 511-45-2, $98-100 \mathrm{~cm}$, being rare or very rare in other parts of its stratigraphic range.

Age. Turonian-lower Campanian.

Remarks. Sliter (1977, p. 522) mentioned and illustrated tests of this species as incertae sedis from Santonian sediments of Site 327, Falkland Plateau (Leg 36). He noted that its stratigraphic distribution was limited to within the Santonian interval, represented mostly by dissolution facies, where this species was abundant. We refer this very characteristic form to the new species and new genus Sliteria. It is readily distinguished from all other known taxons of calcispherulids by its polyhedral test with pentaradiate symmetry and numerous peculiar apertures. Certainly the assignment of $S$. pentagonalis to calcispherulids is very conditional and preliminary, but spherical adult specimens strongly resemble ordinary, porous calcispherulids.

\section{ACKNOWLEDGMENTS}

The authors wish to thank the Deep Sea Drilling Project for having given them the opportunity to participate on Leg 71 of the Glomar Challenger. While preparing this article, the authors discussed many aspects of the morphology and stratigraphic distribution of Cretaceous calcispherulids with Dr. E. P. Radionova (Geological Institute 
of the U.S.S.R. Academy of Sciences). They wish to express their thanks to her. Gratitude is also expressed to Mr. V. Bernard (Institute of the Lithosphere of the U.S.S.R. Academy of Sciences) and Ms. I. Zenjakina (Geological Institute of the U.S.S.R. Academy of Sciences) for preparing all SEM micrographs.

\section{REFERENCES}

Banner, F. T., 1972. Pithonella ovalis from the early Cenomanian of England. Micropaleontology, 18:278-284.

Bein, A., and Reiss, Z., 1976. Cretaceous Pithonella from Israel. Micropaleontology, 22:83.

Bolli, H. M., 1974. Jurassic and Cretaceous Calcisphaerulidae from DSDP Leg 27, Eastern Indian Ocean. In Veevers J. J., Heirtzler, J. R., et al., Init. Repts. DSDP, 27: Washington (U.S. Govt. Printing Office), 843-907.

1978. Cretaceous and Paleogene Calcisphaerulidae from DSDP Leg 40, southeastern Atlantic. In Bolli, H. M., Ryan, W. B.
F., et al., Init. Repts. DSDP, 40: Washington (U.S. Govt. Printing Office), 819-837.

Keupp, H., 1979. Lower Cretaceous Calcisphaerulidae and their relationship to calcareous dinoflagellate cysts. Bull. Cent. Rech. Explor.-Prod., Elf-Aquitaine, 3(no. 2):651-663.

Pflaumann, U., and Krasheninnikov, V. A., 1978. Cretaceous calcisphaerulids from DSDP Leg 41, eastern north Atlantic. In Lancelot, Y., Seibold, E., et al., Init. Repts. DSDP, Suppl. to Vols. 38, 39,40 , and 41: Washington (U.S. Govt. Printing Office), 817-839.

Rögl, F., 1976. Danian Calcisphaerulidae of DSDP Leg 35, Site 323, Southeast Pacific Ocean. In Hollister, C. D., Craddock, C., et al., Init. Repts. DSDP, 35: Washington (U.S. Govt. Printing Office), 701-712.

Sliter, W. V., 1977. Cretaceous foraminifers from the southwestern Atlantic Ocean, Leg 36, Deep Sea Drilling Project, In Barker, P. F., Dalziel, I. W. D., et al., Init. Repts. DSDP, 36: Washington (U.S. Govt. Printing Office), 519-574. 


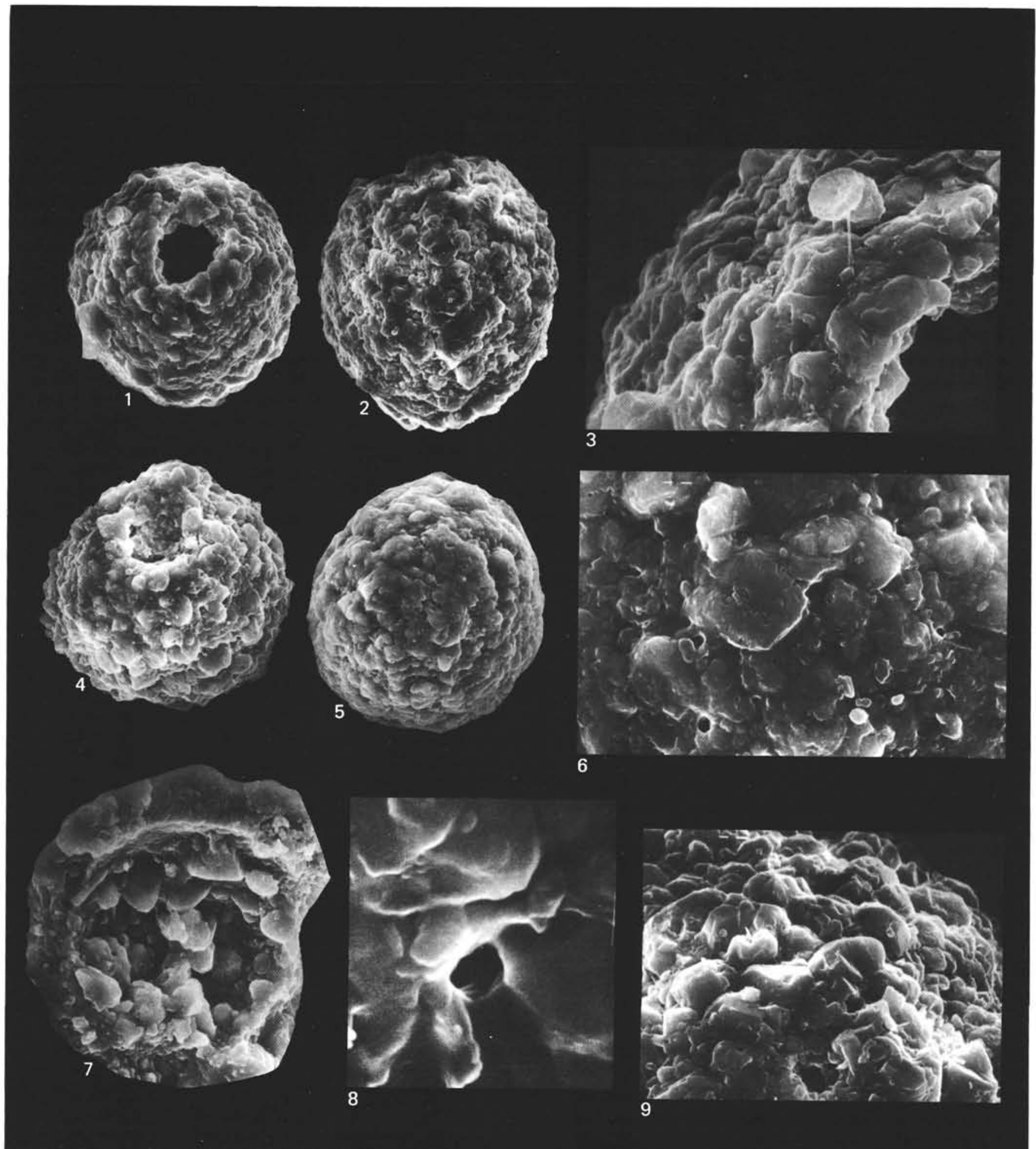

Plate 1. Pithonella thayeri, Sample 511-51,CC. 1. Apertural view, $\times 600$. 2. Side view, $\times 600$. 3. Apertural area, $\times 2000$. 4. Side/apertural view, $\times 600$. 5. Distal view, $\times 600$. 6. Outer surface showing irregular shape of crystals and rare pores between them, $\times 2000$. 7. Cross-section of the wall and inside view, $\times 800$. 8. Outer surface showing a pore and disposition of crystals around it, $\times 15,000$. 9. Detail showing uneven surface, $\times 2000$. 

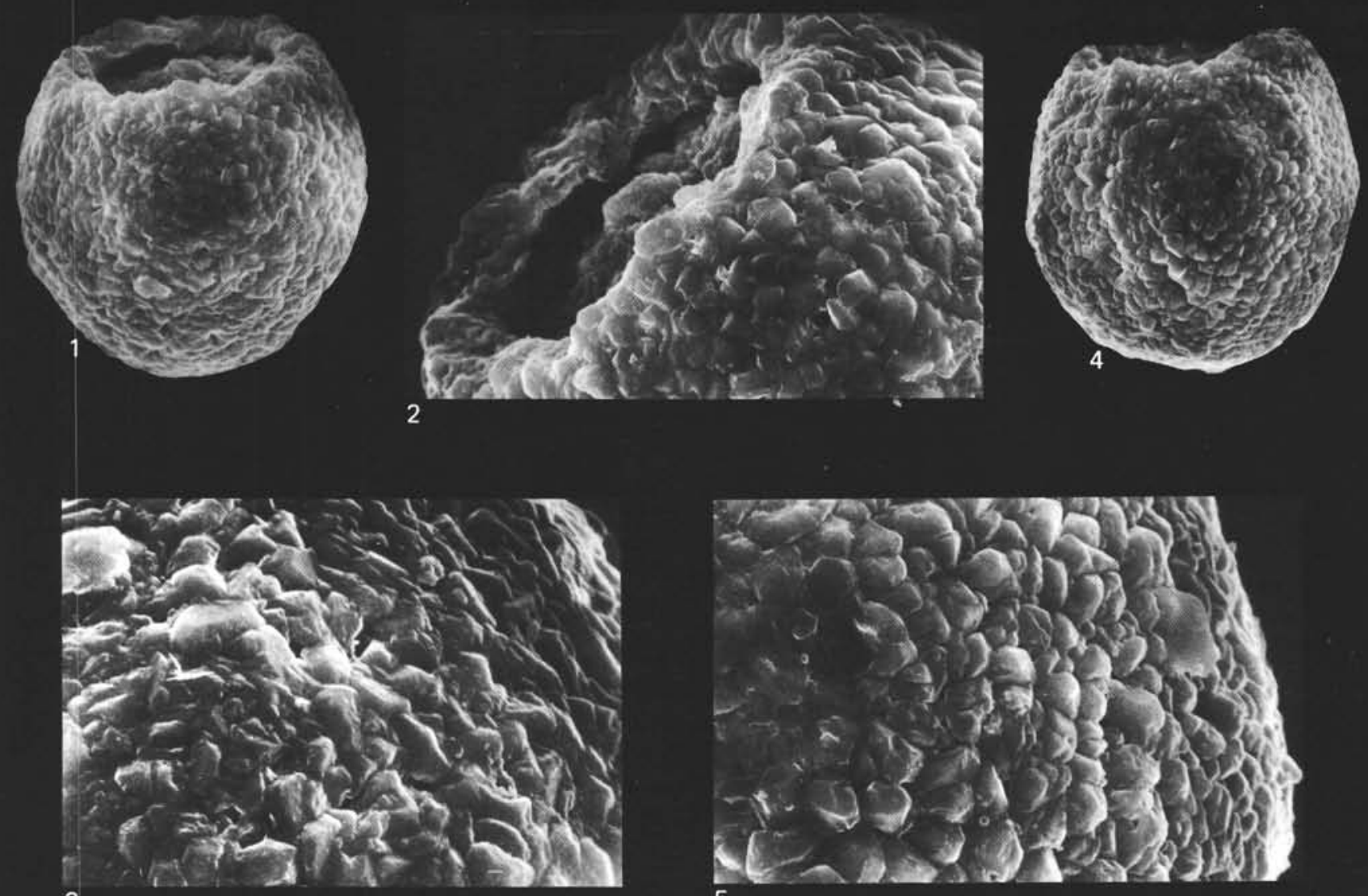

3

5
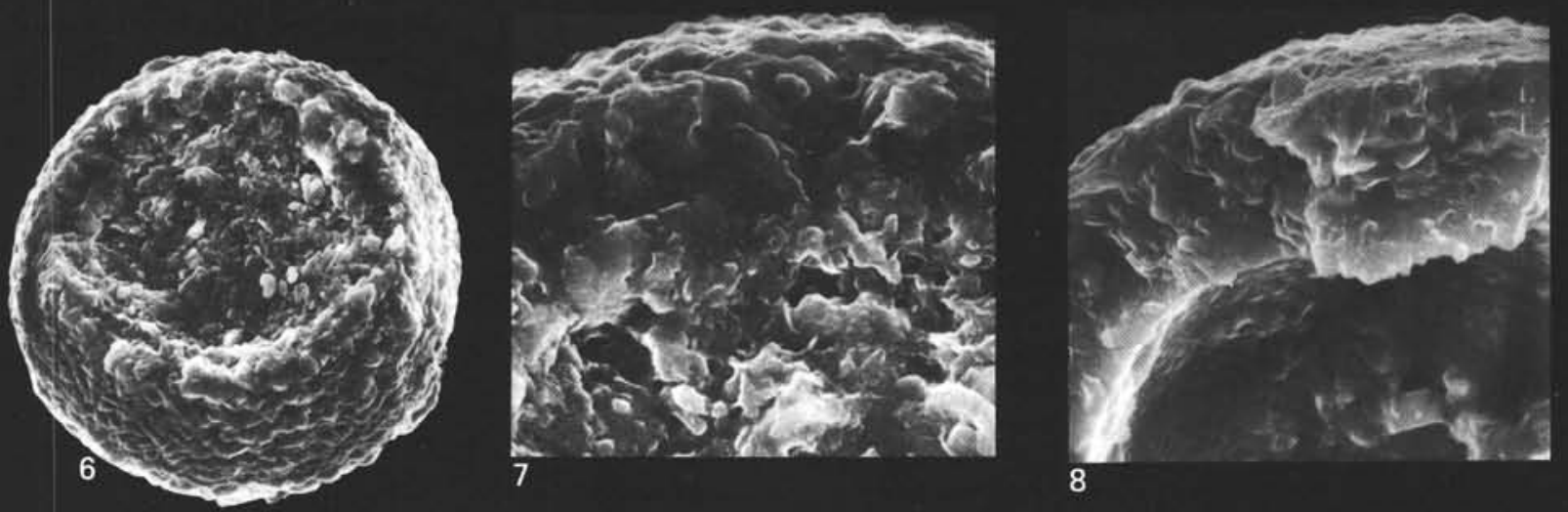

Plate 2. Pithonella sheilasantawae, Sample $511-50-3,44-46 \mathrm{~cm} . \quad 1$. Side/apertural view, $\times 600 . \quad 2$. Aperture and apertural area, $\times 1200$. 3,5 . Details showing regular crystals forming cobblestone-like appearance of the outer surface; minute pores are visible between crystals; $\times 2000$. 4 . Side/apertural view, $\times 600$. 6. Apertural view showing the large aperture, $\times 700$. 7. Cross-section of double-layered wall, $\times 2000$. 8 . Crosssection showing double-layered wall and smooth inner surface, $\times 2000$. 

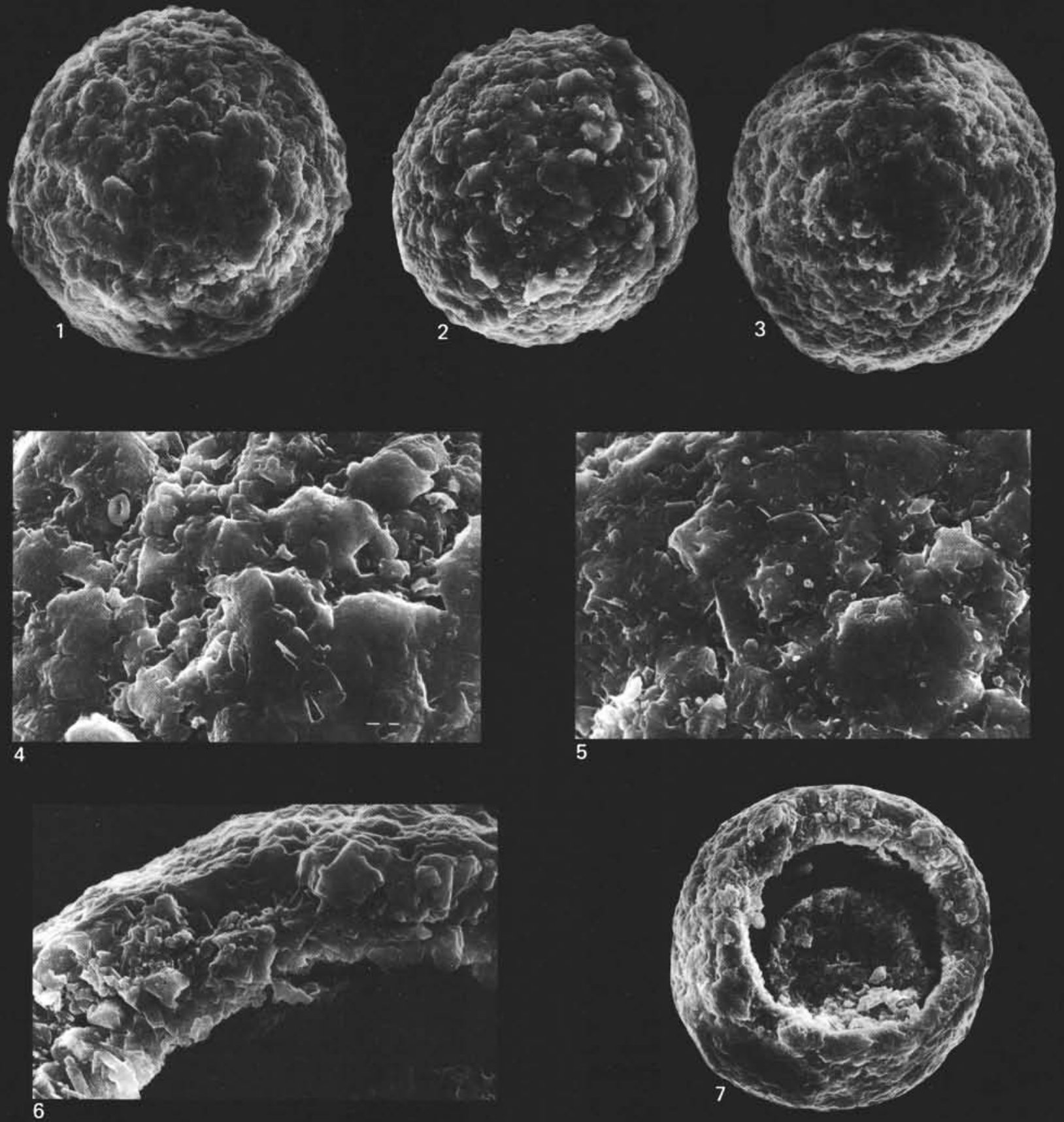

Plate 3. Pithonella loricata $\mathrm{n} . \mathrm{sp}$., Sample $511-55-3,34-36 \mathrm{~cm}$. 1. Holotype, $\times 600.2-3$. Paratypes, $\times 600$. 4-5. Outer surface of (4) holotype and (5) paratype with platelike crystals of irregular outline, $\times 2000$. 6. Cross-section of the wall; two layers separated by uneven surface are visible, $\times 2000$. 7. Specimen with top of shell destroyed (large aperture?), $\times 600$. 

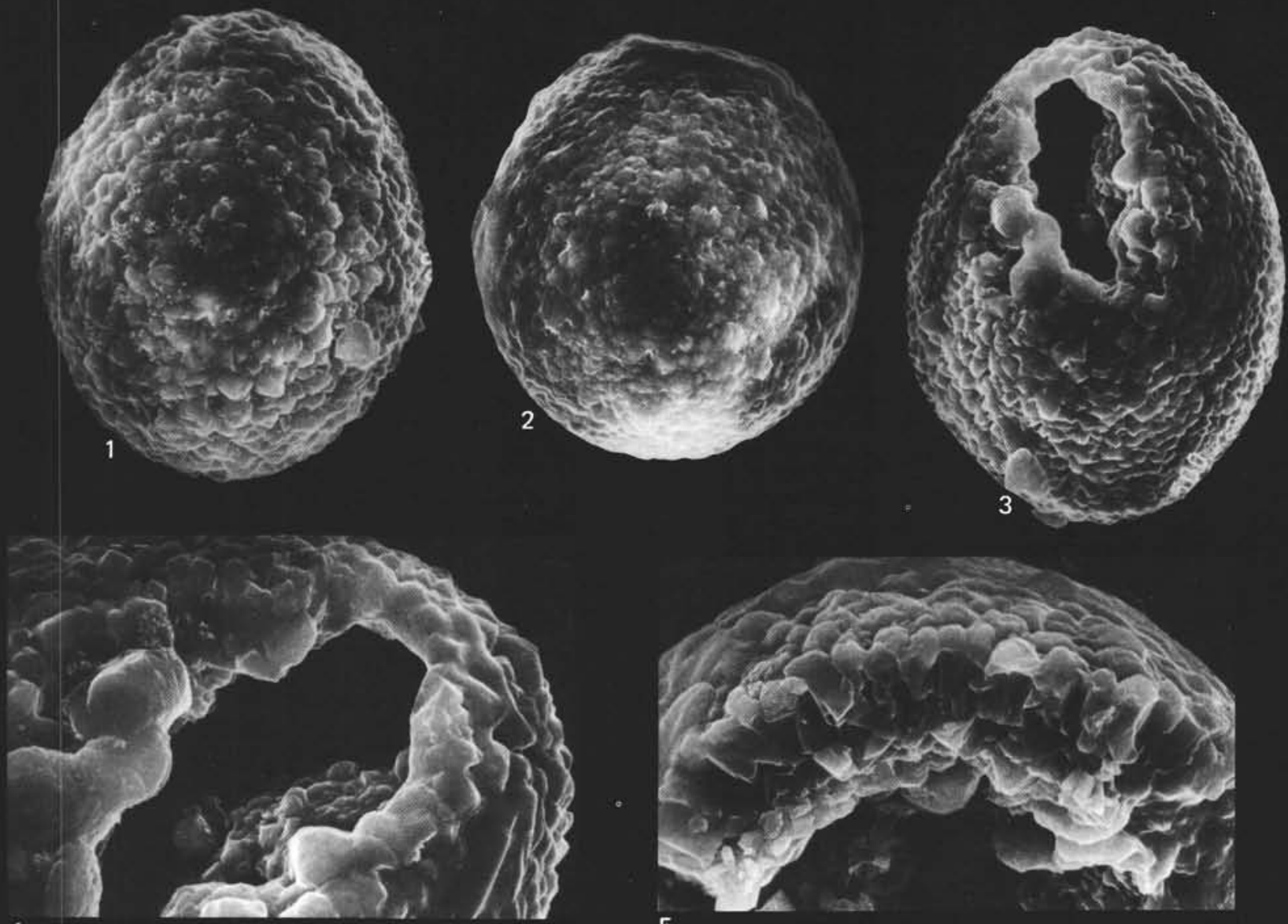

4
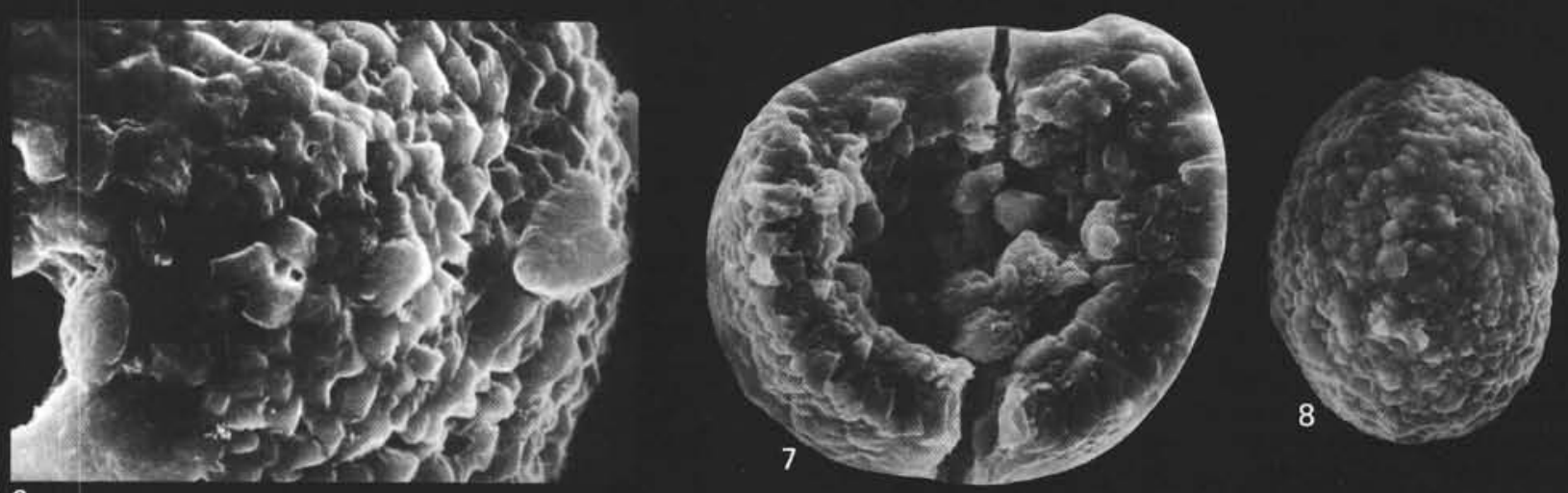

6

Plate 4. Pithonella squalida n.sp., Sample $511-49-5,120-122 \mathrm{~cm} . \quad 1-2$. Side view of paratypes, $\times 1000$. 3. Apertural view of holotype, $\times 1000$. 4. Apertural area with cobblestonelike crystals fringing the aperture, $\times 2000$. 5. Cross-section of wall of paratype with two layers, $\times 2000$. 6 . Holotype, showing part of the aperture and uneven outer surface with small irregularly distributed pores and cobblestonelike crystals, $\times 1000$. 7. Cross-section of paratype showing double-layered wall and uneven inner surface with protruding crystals, $\times 1000$. 8 . Side view of paratype, $\times 600$. 

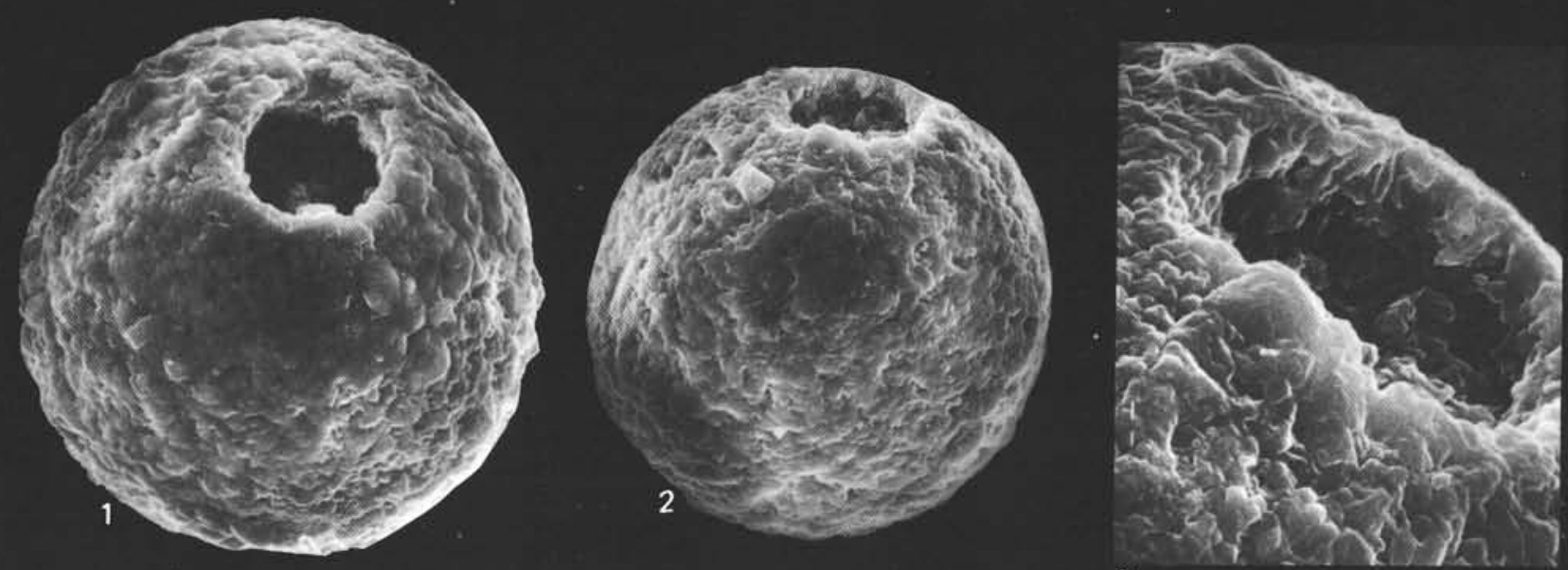

3

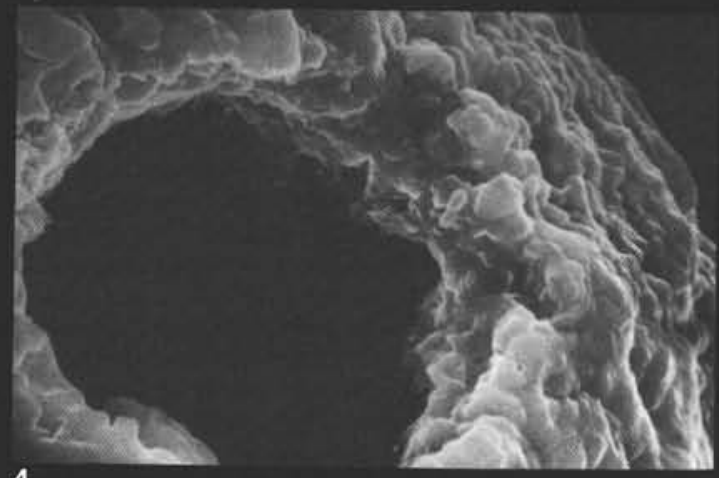

4
6

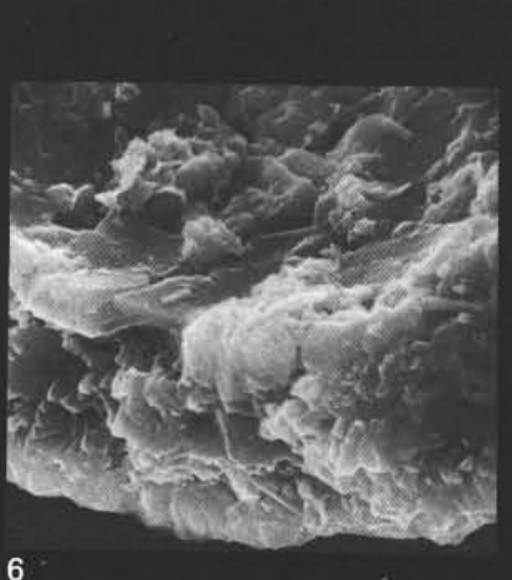

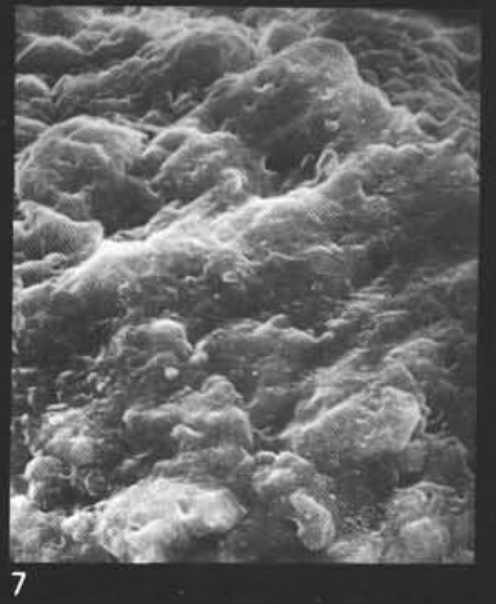

Plate 5. Pithonella miniaperta n.sp., Sample $511-50-3,44-46 \mathrm{~cm}$. 1. Apertural view of holotype, $\times 600.2$. Side/apertural view of paratype, $\times 600$. 3-4. Paratype, $\times 2000$ (3) showing aperture and apertural area, (4) showing aperture with platelike crystals around it. 5-6. Threelayered wall and relatively even inner surface formed by flat, tightly arranged crystals, $\times 2000$. 7-8. Holotype (7) and paratype (8) showing outer surface with flat, platelike crystals and minute, irregularly dispersed pores, $\times 2000$. 


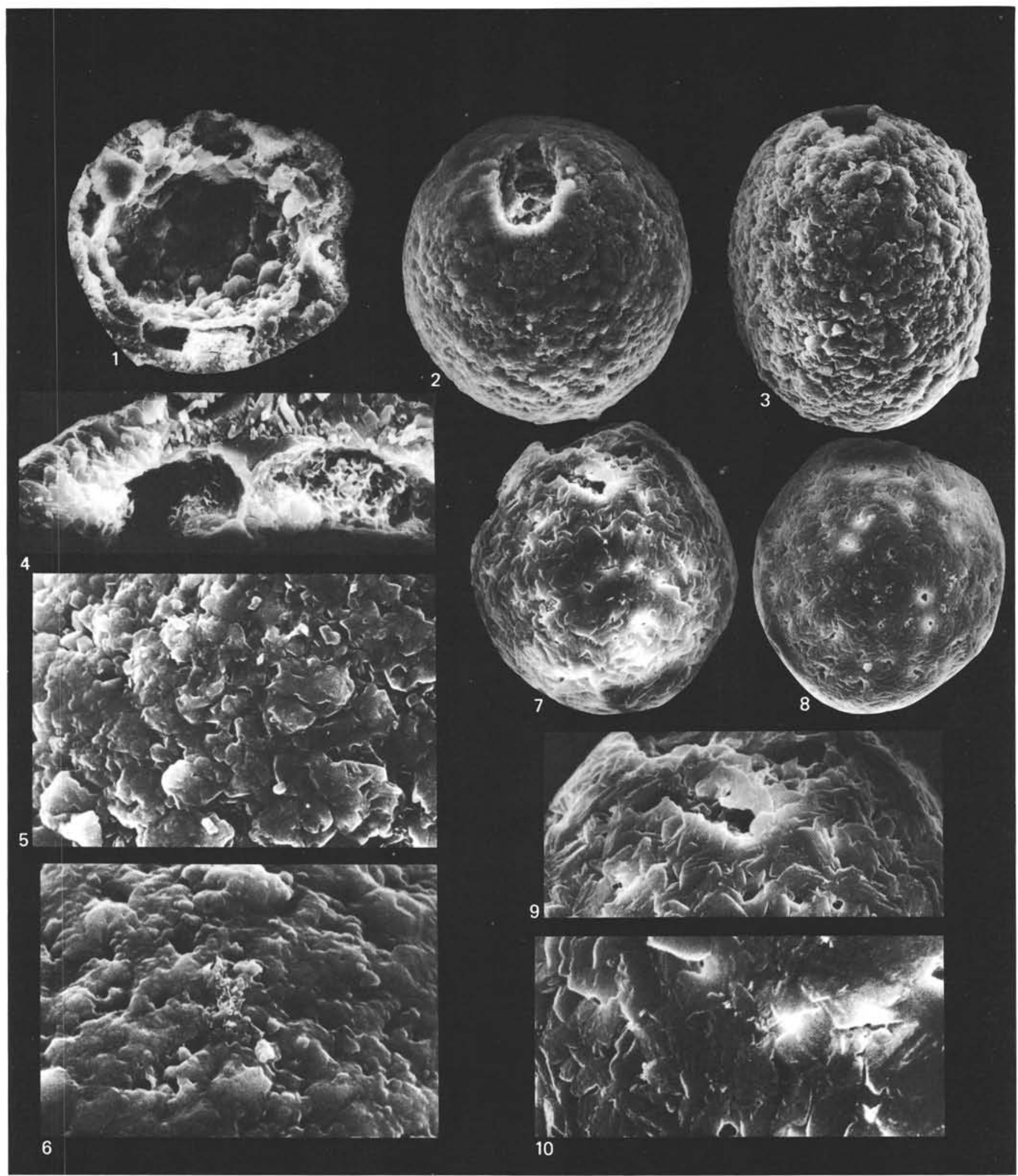

Plate 6. 1-6. Pithonella squamosa n.sp., Sample 511-50,CC, (1) cross-section showing double-layered wall with cavities and inner surface with protruding crystals that are possibly of secondary origin, $\times 600,(2)$ apertural view of paratype, $\times 600,(3)$ side/apertural view of holotype, $\times 600$, (4) paratype showing structure of wall (outer layer and cavities), $\times 2000$, (5-6) holotype (5) and paratype (6) showing outer surface with tiny pores, $\times 2000$. 7-10. Pithonella ex gr. francadecimae, Sample 511-47-5, 44-46 cm, (7-8) side/apertural view, $\times 600$, (9) apertural area and outer surface with platelike crystals and irregularly dispersed pores, $\times 1200,(10)$ outer surface with small pores, $\times 2500$. 


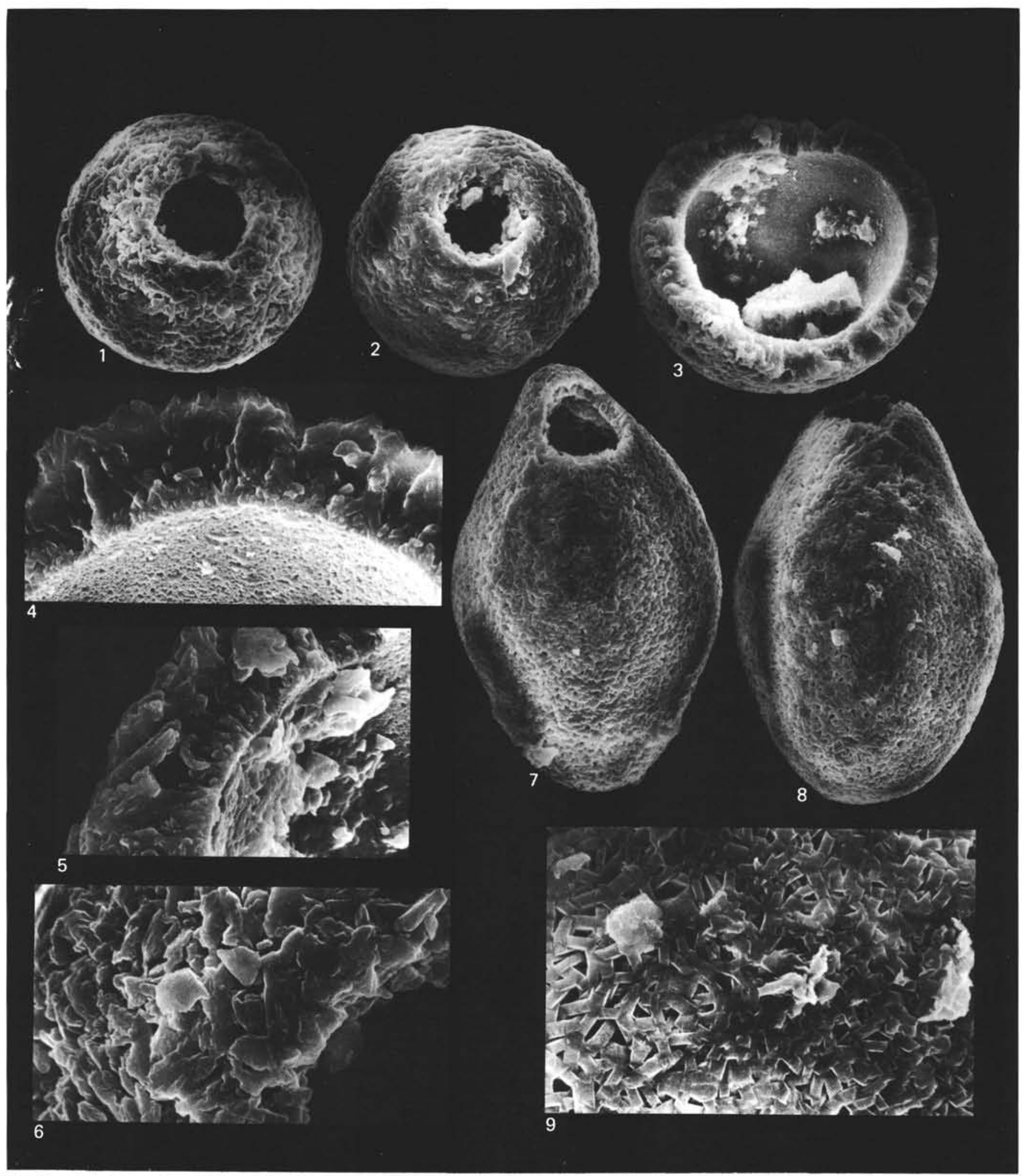

Plate 7. 1-6. Pithonella transitoria n.sp., Sample $511-41-3,55-57 \mathrm{~cm},(1)$ apertural view of holotype, $\times 600,(2)$ apertural view of paratype, $\times 600$, (3) cross-section of paratype showing double-layered wall and smooth inner surface, $\times 700,(4-5)$ paratype showing two-layer structure of wall, $\times 2000$. (6) holotype showing apertural area, outer surface, and form of crystals, $\times 2000$. 7-9. Pithonella usheri n.sp., Sample 511-25,CC, (7-8) side/apertural views, $\times 500$ (7, holotype showing drop-shaped test with asymmetrically situated aperture; 8 , paratype showing smooth outer surface), (9) paratype showing even surface of the outer layer, composed of small elongated crystals, $\times 2000$. 


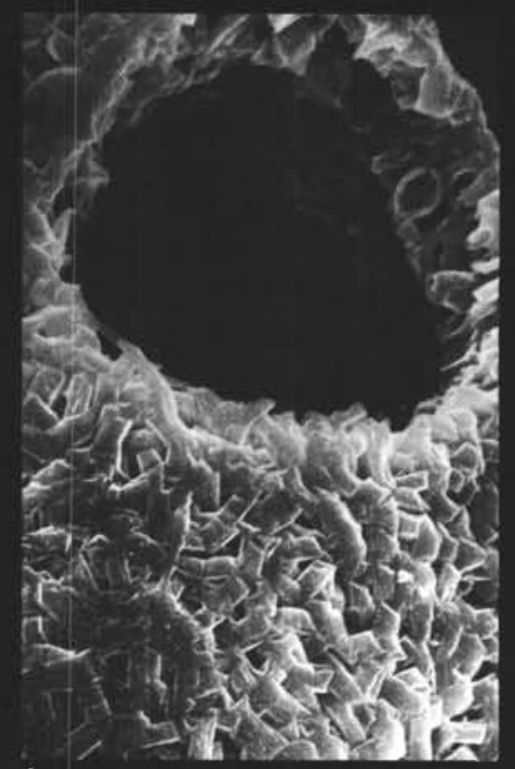

1

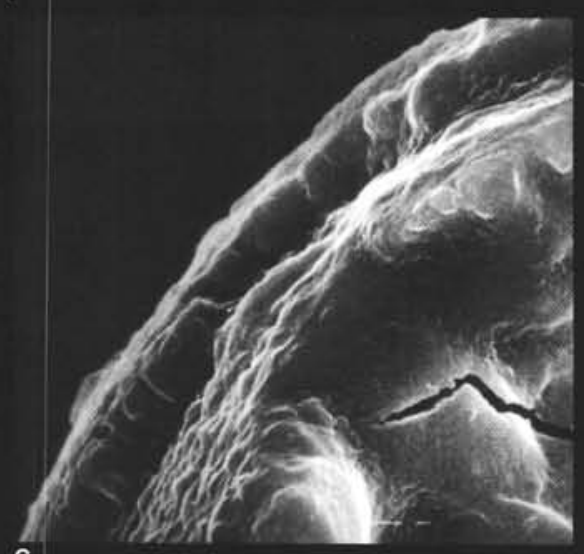

6

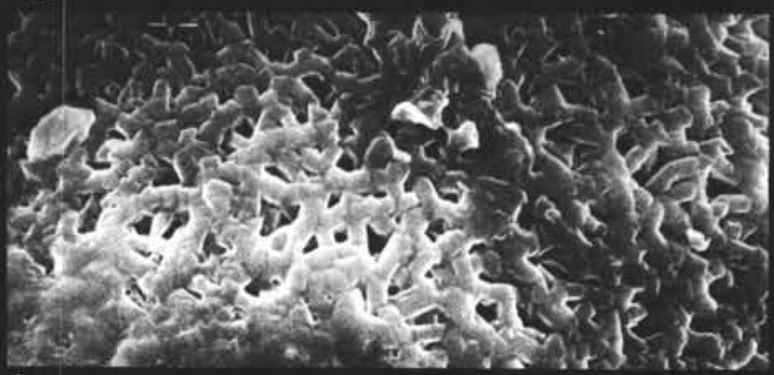
7

2

5
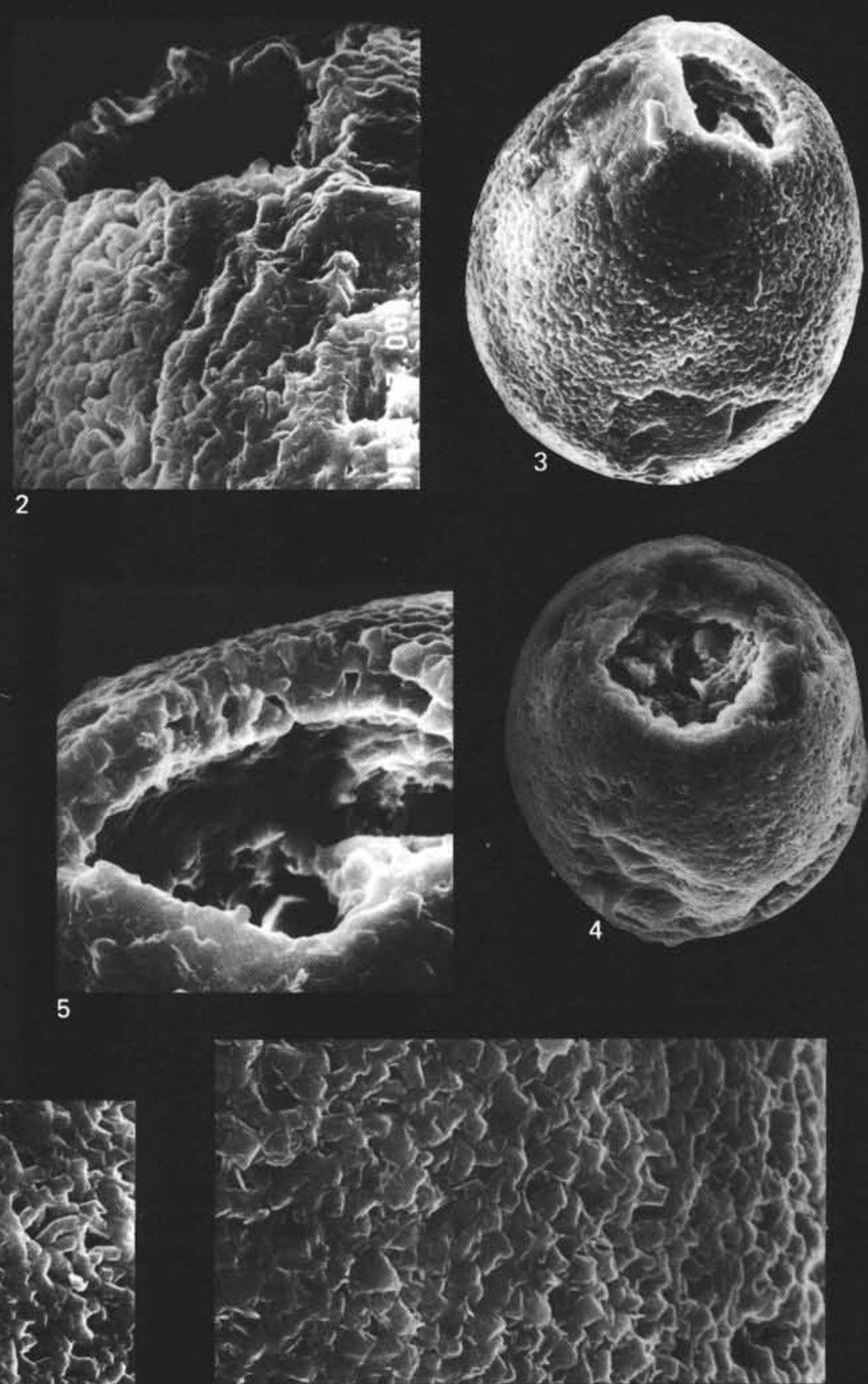

8

Plate 8. 1-2. Pithonella usheri $\mathrm{n}$. sp., Sample 511-25,CC, $\times 1800$; aperture and apertural area of (1) holotype with visible two-layered wall and (2) paratype. 3-8. Pithonella bilamellata (3) side/apertural view showing smooth outer surface with small, elongated crystals and massive crystals of the inner layer (in a place where outer layer is destroyed), $\times 600$, Sample 511-25,CC, (4) apertural view, $\times 700$, Sample 511-24-7, 15-17 cm, (5) apertural area, $\times 2000$, Sample 511-25,CC. (6) cross-section of wall with thin outer layer composed of small crystals and thick inner layer consisting of large massive crystals, $\times 3500$, Sample $511-25, C C,(7-8)$ outer surface, $\times 2000(7$, Sample 511-25,CC; 8, Sample 511-24-7, 15-17 cm). 

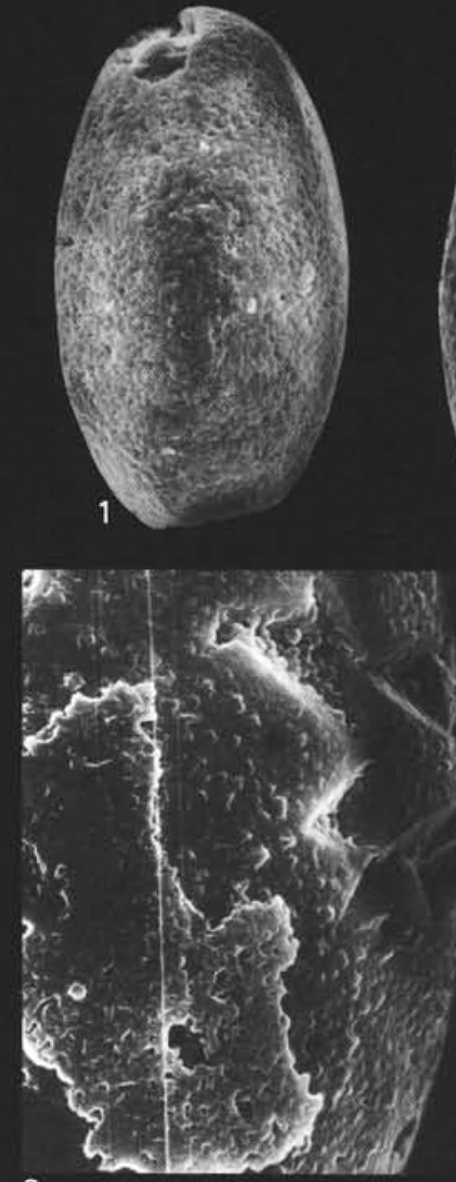

9

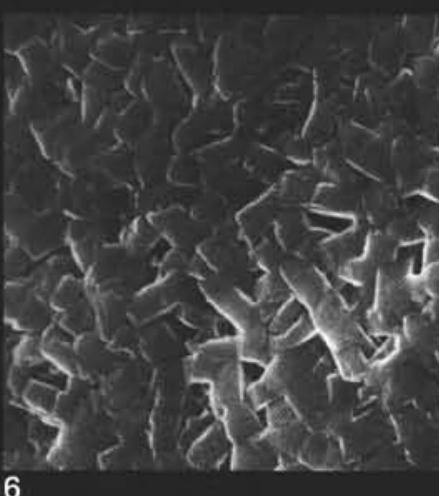

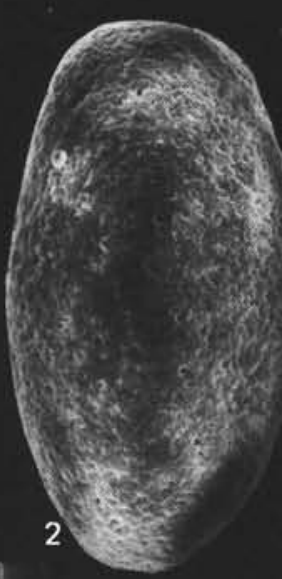
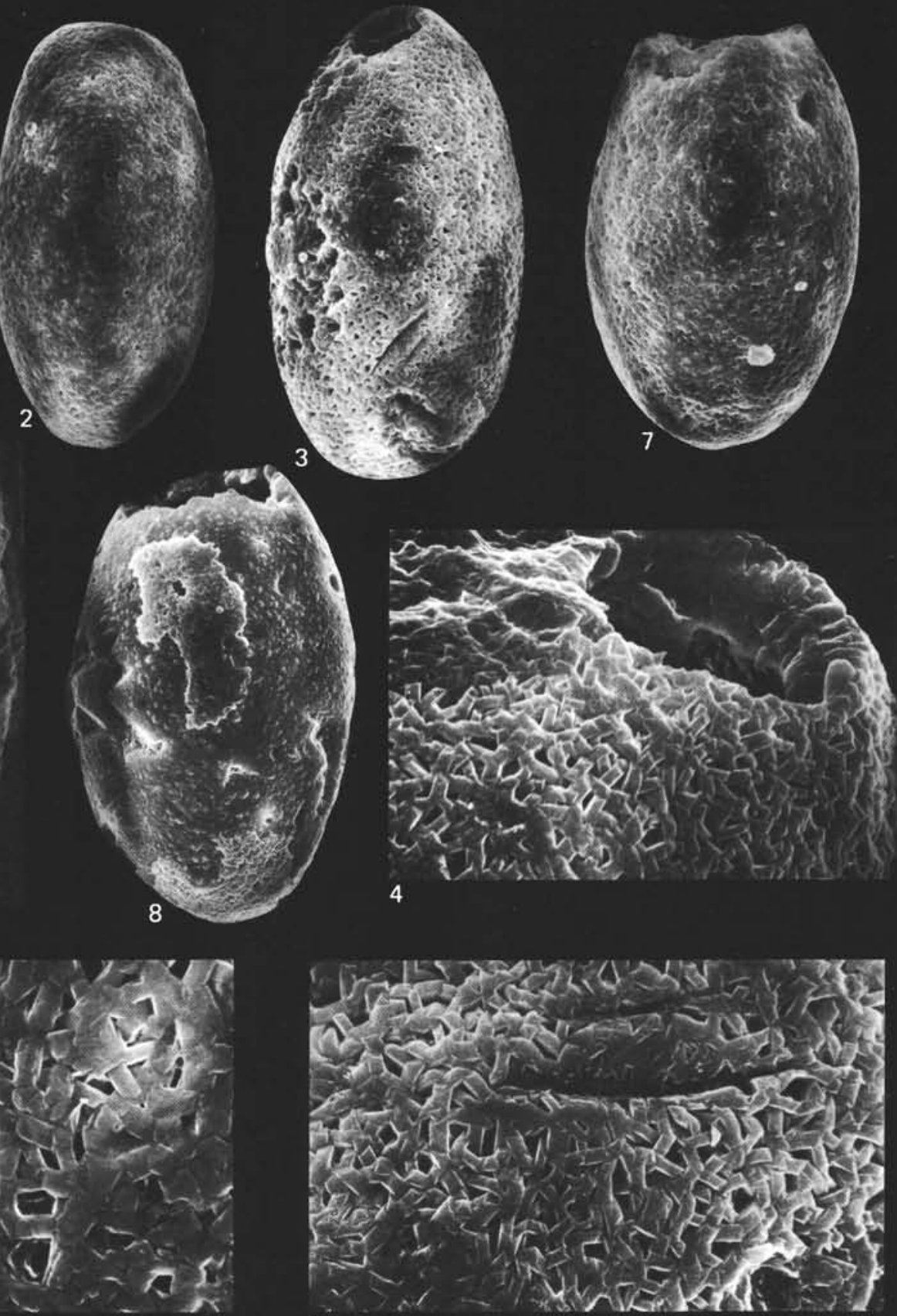

5

Plate 9. Pithonella krasheninnikovi. 1-2. Side view, $\times 500$, Sample 511-24-7, $15-17 \mathrm{~cm} .3$. Side/apertural view, $\times 500$, Sample $511-25, \mathrm{CC}$. 4. Apertural area, $\times 1500$, Sample 511-25,CC. 5. Outer surface with small elongated crystals, $\times 2000$, Sample $511-25$, CC. 6 . Outer surface, $\times 4000$, Sample $511-24,7,15-17 \mathrm{~cm}$. 7. Side view, $\times 500$, Sample $511-24-7,15-17 \mathrm{~cm} . \quad 8$. Side/apertural view of a specimen with mostly destroyed thin outer layer, $\times 600$, Sample $511-24-7,15-17 \mathrm{~cm}$. 9. Detail showing partly preserved thin outer layer and thick inner layer composed of large, massive crystals, $\times 1200$, Sample $511-24-7,15-17 \mathrm{~cm}$. 

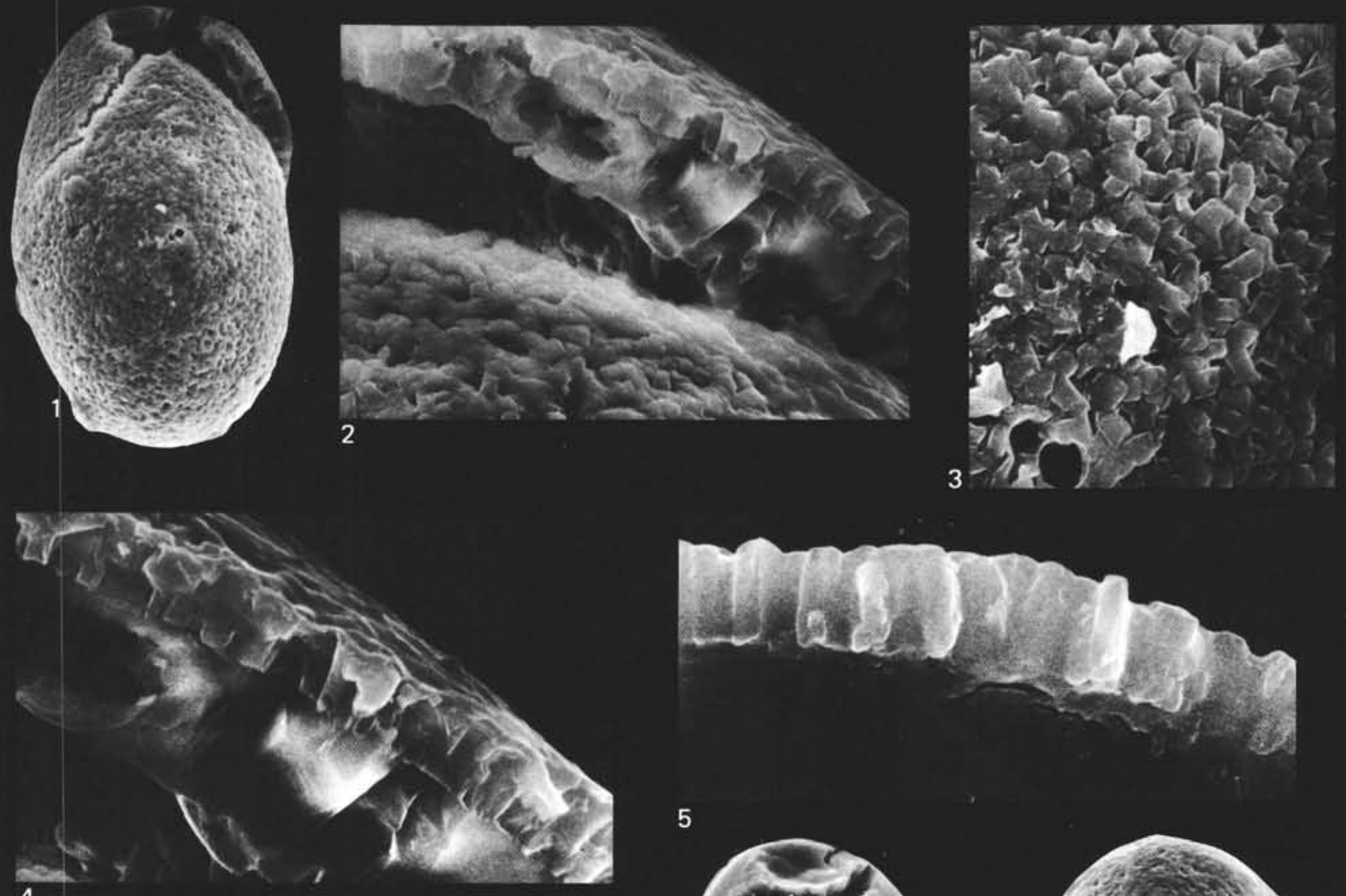

4

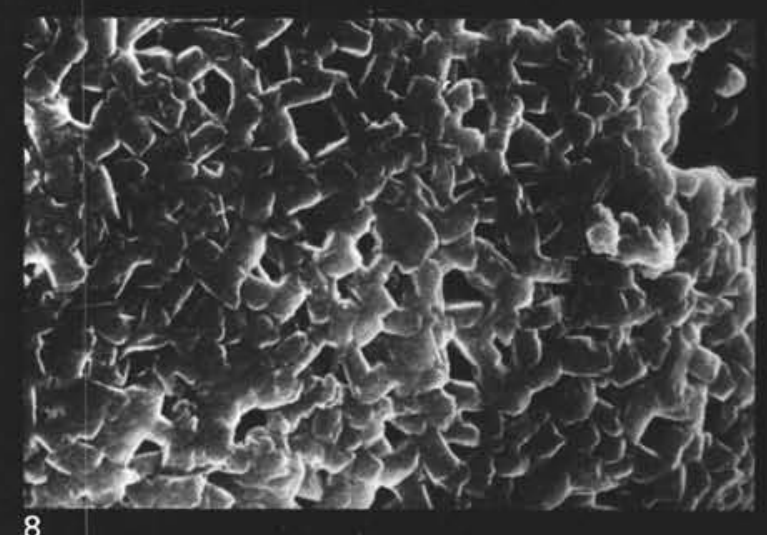
8

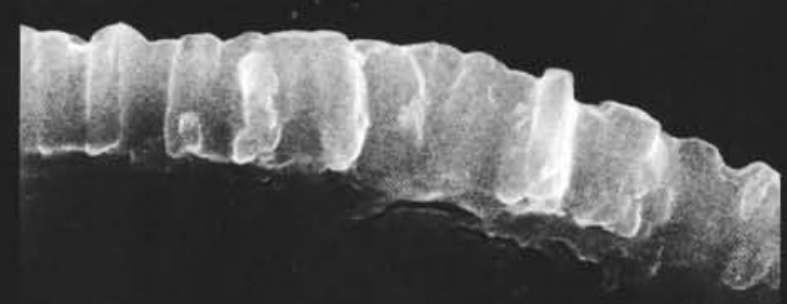

5
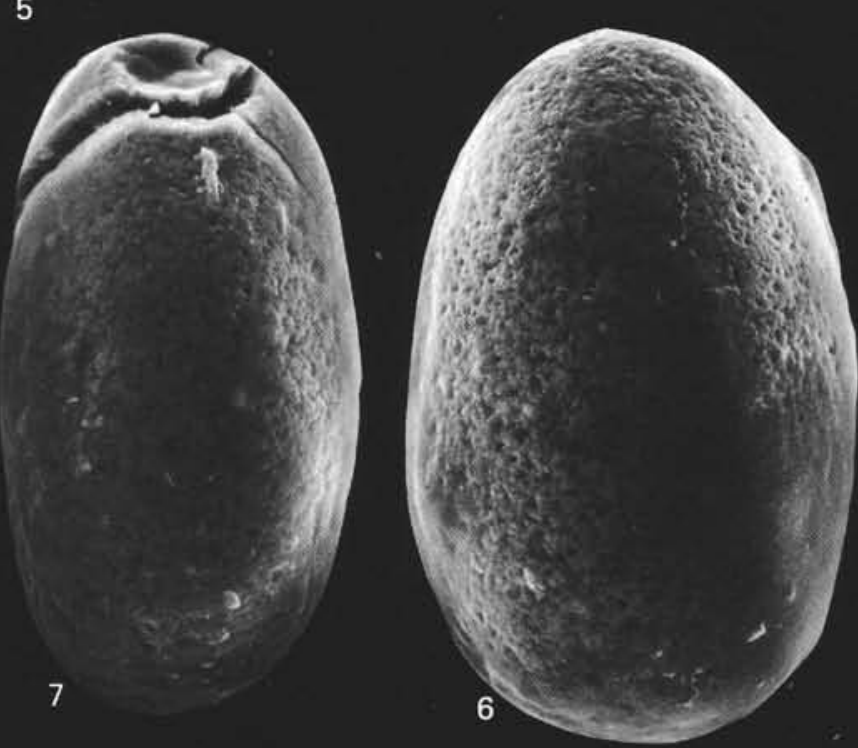

Plate 10. 1-5. Pithonella krasheninnikovi, Sample 511-25,CC, (1) side/apertural view of partly broken specimen, $\times 500$, (2) structure of the wall with two layers, $\times 2000$, (3) outer surface with closely arranged small, elongated crystals, $\times 2000$, (4) cross-section of the wall with thin outer layer and thick, massive inner layer, $\times 3000$, (5) cross-section of outer layer, composed of small, columnar crystals, and thick, massive inner layer, $\times 4000$. 6-8. Pithonella cylindrica, Sample 511-24-7, 15-17 cm, (6) side view, $\times 500$, (7) side/apertural view, $\times 600,(8)$ smooth outer surface with small, slightly elongated crystals, $\times 3000$. 


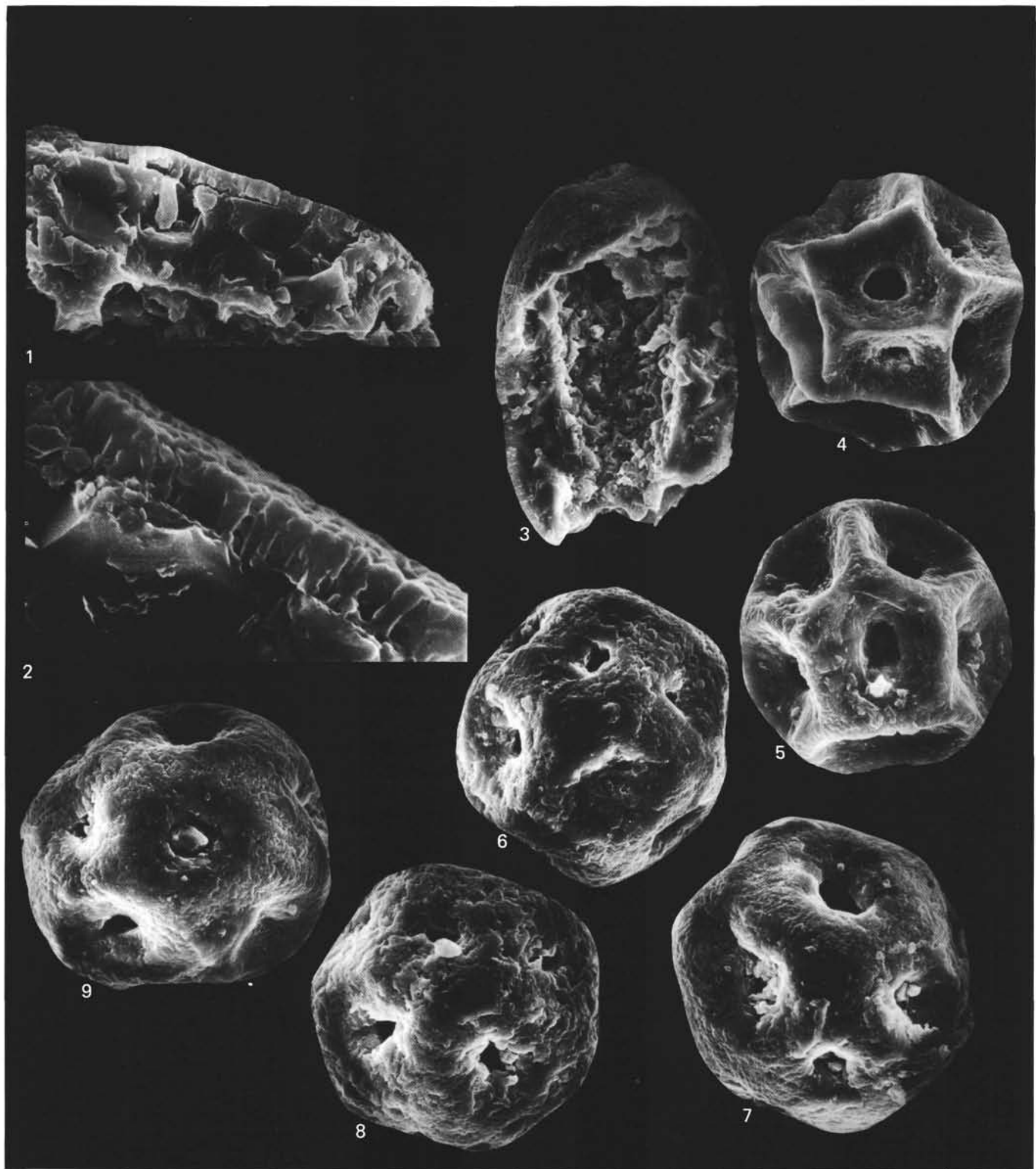

Plate 11. 1-3. Pithonella cylindrica, Sample 511-24-7, 15-17 cm, (1) cross-section of wall with two distinct layers, $\times 1200,(2)$ structure of wall with thin outer layer composed of small columnar crystals and thick inner layer consisting of large, massive crystals, $\times 5000,(3)$ side/apertural view of artificially broken specimen; smooth outer surface, uneven inner surface, and double-layered wall, $\times 600$. 4-9. Sliteria pentagonalis n.sp. et gen, (4-5) apertural view, $\times 600$, Sample 511-42,CC (4, holotype; 5, paratype), (6-9) Paratypes with closed, different-grade supplementary apertures, $\times 600$, Sample $511-43-4,62-64 \mathrm{~cm}$. 

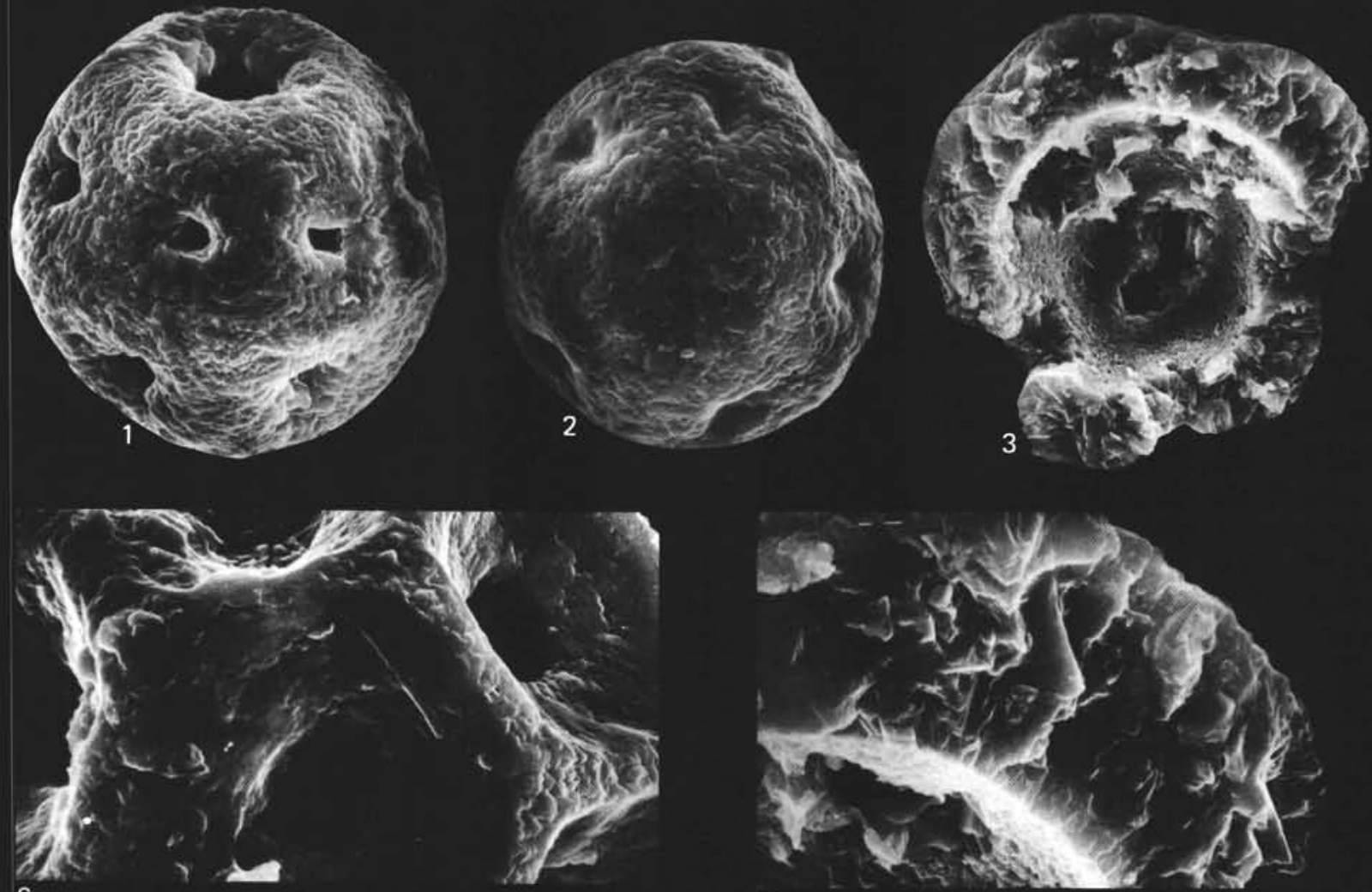

4
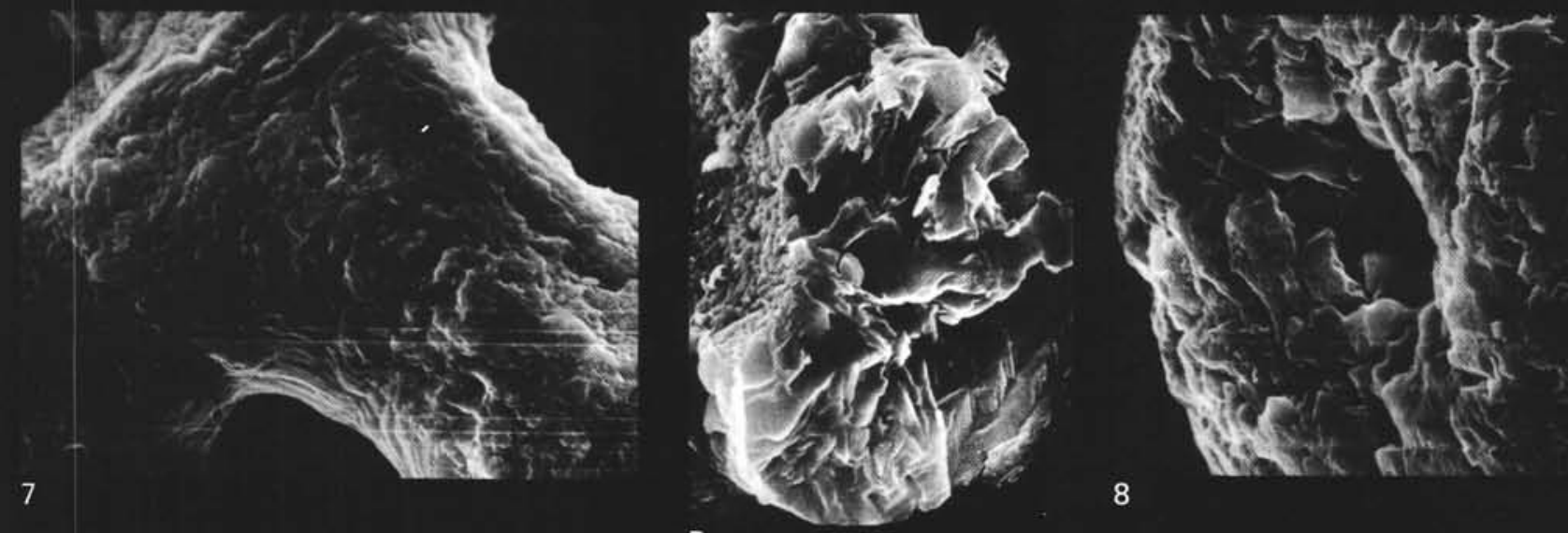

5

Plate 12. Sliteria pentagonalis n.sp. et gen. 1-2. Spherical specimens (paratypes) with larger main aperture and semiclosed supplementary apertures, $\times 600$, Sample $511-42$, CC. 3. Cross-section of paratype showing single-layered wall and smooth, porous inner surface, $\times 700$, Sample $511-43-4,62-64 \mathrm{~cm}$. 4-5. Paratype showing cross-section of (4) wall and (5) knot formed by junction of three apertural partitions, $\times 2200$, Sample 511-43-4, 62-64 cm. 6. Paratype showing apertures and partitions between them, $\times 1200$, Sample 511-42,CC. 7-8. Paratype, $\times 2000$, Sample 511-43-4, 62-64 cm, showing (7) partition surface, (8) a supplementary aperture and apertural area. 